\title{
Chemical characterization of SOA formed from aqueous-phase reactions of phenols with the triplet excited state of carbonyl and hydroxyl radical
}

\author{
L. Yu ${ }^{1}$, J. Smith ${ }^{2}$, A. Laskin ${ }^{3}$, C. Anastasio ${ }^{2}$, J. Laskin ${ }^{4}$, and Q. Zhang ${ }^{1}$ \\ ${ }^{1}$ Department of Environmental Toxicology, University of California, 1 Shields Ave., Davis, CA 95616, USA \\ ${ }^{2}$ Department of Land, Air and Water Resources, University of California, 1 Shields Ave., Davis, CA 95616, USA \\ ${ }^{3}$ Environmental Molecular Sciences Laboratory, Pacific Northwest National Laboratory, Richland, WA 99352, USA \\ ${ }^{4}$ Physical Sciences Division, Pacific Northwest National Laboratory, Richland, WA 99352, USA
}

Correspondence to: Q. Zhang (dkwzhang@ucdavis.edu)

Received: 3 August 2014 - Published in Atmos. Chem. Phys. Discuss.: 19 August 2014

Revised: 2 November 2014 - Accepted: 23 November 2014 - Published: 23 December 2014

\begin{abstract}
Phenolic compounds, which are emitted in significant amounts from biomass burning, can undergo fast reactions in atmospheric aqueous phases to form secondary organic aerosol (aqSOA). In this study, we investigate the reactions of phenol (compound with formula $\left.\mathrm{C}_{6} \mathrm{H}_{5} \mathrm{OH}\right)$ ), guaiacol (2-methoxyphenol), and syringol (2,6-dimethoxyphenol) with two major aqueous-phase oxidants - the triplet excited states of an aromatic carbonyl $\left({ }^{3} \mathrm{C}^{*}\right)$ and hydroxyl radical $(\cdot \mathrm{OH})$. We thoroughly characterize the low-volatility species produced from these reactions and interpret their formation mechanisms using aerosol mass spectrometry (AMS), nanospray desorption electrospray ionization mass spectrometry (nano-DESI MS), and ion chromatography (IC). A large number of oxygenated molecules are identified, including oligomers containing up to six monomer units, functionalized monomer and oligomers with carbonyl, carboxyl, and hydroxyl groups, and small organic acid anions (e.g., formate, acetate, oxalate, and malate). The average atomic oxygen-to-carbon $(\mathrm{O} / \mathrm{C})$ ratios of phenolic aqSOA are in the range of $0.85-1.23$, similar to those of low-volatility oxygenated organic aerosol (LV-OOA) observed in ambient air. The aqSOA compositions are overall similar for the same precursor, but the reactions mediated by ${ }^{3} \mathrm{C}^{*}$ are faster than . OH-mediated reactions and produce more oligomers and hydroxylated species at the point when $50 \%$ of the phenolic compound has reacted. Profiles determined using a thermodenuder indicate that the volatility of phenolic aqSOA is influenced by both oligomer content and $\mathrm{O} / \mathrm{C}$ ratio. In ad-
\end{abstract}

dition, the aqSOA shows enhanced light absorption in the UV-visible region, suggesting that aqueous-phase reactions of phenols may contribute to formation of secondary brown carbon in the atmosphere, especially in regions influenced by biomass burning.

\section{Introduction}

Secondary organic aerosol (SOA) is ubiquitous in the atmosphere (Murphy et al., 2006; Zhang et al., 2007; Jimenez et al., 2009) and plays an important role in climate, human health, and air quality. Thus, understanding the impacts of SOA requires a thorough knowledge of the formation, evolution, and composition of SOA. This knowledge, however, is still limited because atmospheric organic chemistry is extremely complex. Numerous sources emit organic compounds and organic aerosol is formed and transformed via complicated chemical and physical processes in the atmosphere (Kanakidou et al., 2005).

SOA formation can take place in both the gas and condensed phases. Much of the previous research on SOA has mainly focused on gas-phase reactions of volatile organic compounds (Hallquist et al., 2009). Recent work, however, has shown that SOA can also be produced efficiently in cloud and fog drops and water-containing aerosol (Blando and Turpin, 2000; Lim et al., 2005; Altieri et al., 2006; Ervens et al., 2011). Understanding the characteristics of SOA 
formed from aqueous-phase reactions (aqSOA) is important for properly representing its formation pathways in models and for elucidating its climatic and health effects.

Phenols are important precursors of aqSOA because (1) they are emitted in large quantities from biomass burning (Hawthorne et al., 1989; Schauer et al., 2001); (2) they have high Henry's law constants and can partition significantly into atmospheric aqueous phases (Sagebiel and Seiber, 1993; Sander, 1999); and (3) they can undergo fast reactions with hydroxyl radical $(\cdot \mathrm{OH})$ in aqueous phase and triplet excited states of organic compounds $\left({ }^{3} \mathrm{C}^{*}\right)$ formed via light absorption by dissolved chromophores (Anastasio et al., 1997; Canonica et al., 2000; Smith et al., 2014). In the aqueous phase, $\cdot \mathrm{OH}$ is usually considered a dominant oxidant for organics. However, a recent study by Smith et al. (2014) showed that the destruction rates of phenols by ${ }^{3} \mathrm{C}^{*}$ are comparable to or faster than those by $\cdot \mathrm{OH}$ under typical ambient conditions in areas influenced by biomass burning. An important source of ${ }^{3} \mathrm{C}^{*}$ in the atmosphere is non-phenolic aromatic carbonyls - a group of compounds that are emitted from wood combustion in significant amounts (Hawthorne et al., 1992; Simoneit et al., 1999) and have been detected in fog and cloud droplets (Leuenberger et al., 1985; Sagebiel and Seiber, 1993). These compounds, once dissolved in water, can absorb light to form ${ }^{3} \mathrm{C}^{*}$ and catalyze the oxidation of phenols with little or no loss of the aromatic carbonyl (Anastasio et al., 1997; Smith et al., 2014). This is an indication that non-phenolic aromatic carbonyls, along with a number of other organic compounds recently reported (Monge et al., 2012; Aregahegn et al., 2013; Rossignol et al., 2014), can act as photosensitizer to promote SOA formation in atmospheric condensed phases.

According to recent studies, phenols react with $\cdot \mathrm{OH}$ and ${ }^{3} \mathrm{C}^{*}$ to form aqSOA with mass yields close to $100 \%$ (Smith et al., 2014), making reaction products that include small organic acids, hydroxylated phenols, and oligomers (Sun et al., 2010). However, since Sun et al. (2010) mainly used an Aerodyne high-resolution time-of-flight aerosol mass spectrometer with an electron impact (EI) ionization source, in which analyte molecules are generally extensively fragmented (Canagaratna et al., 2007), the molecular composition of the phenolic aqSOA was not sufficiently characterized. In addition, since Sun et al. (2010) examined phenol reactions only with $\cdot \mathrm{OH}$, almost nothing is known about the chemistry of aqSOA formed from ${ }^{3} \mathrm{C}^{*}$ reactions.

In this study, we thoroughly characterize the aqueous reaction products of phenols with ${ }^{3} \mathrm{C}^{*}$ produced from a nonphenolic aromatic carbonyl and $\cdot \mathrm{OH}$ from hydrogen peroxide $(\mathrm{HOOH})$ under simulated sunlight illumination. We studied three basic structures of biomass-burning phenols phenol $\left(\mathrm{C}_{6} \mathrm{H}_{6} \mathrm{O}\right)$, guaiacol $\left(\mathrm{C}_{7} \mathrm{H}_{8} \mathrm{O}_{2} ; 2\right.$-methoxyphenol), and syringol $\left(\mathrm{C}_{8} \mathrm{H}_{10} \mathrm{O}_{3} ; 2\right.$,6-dimethoxyphenol $)$. We examine the molecular and bulk compositions of low-volatility species produced from these reactions and use this information to interpret the formation pathways of phenolic aqSOA.

\section{Experimental methods}

\subsection{Phenolic aqSOA samples}

The aqSOA samples of phenol, guaiacol, and syringol were prepared during simulated sunlight illumination under two oxidant conditions: (1) via reaction with ${ }^{3} \mathrm{C}^{*}$ formed from $5 \mu \mathrm{mol} \mathrm{L}^{-1}$ 3,4-dimethoxybenzaldehyde (3,4-DMB) and (2) via reaction with $\cdot \mathrm{OH}$ generated from $100 \mu \mathrm{mol} \mathrm{L}^{-1}$ hydrogen peroxide $(\mathrm{HOOH}$; Table 1). 3,4-DMB was chosen as the photosensitizer in this study to represent non-phenolic aromatic carbonyls, which are emitted in large quantities from wood burning (Schauer et al., 2001), exist nearly exclusively in condensed phases in the atmosphere, and rapidly form ${ }^{3} \mathrm{C}^{*}$ that efficiently oxidizes phenols (Anastasio et al., 1997). Details of the experiments are reported in Smith et al. (2014) and a brief summary is given here. Initial solutions were composed of air-saturated Milli-Q water (resistance $>18 \mathrm{M} \Omega$-cm; Millipore) containing $100 \mu \mathrm{mol} \mathrm{L}^{-1}$ of a single phenol and adjusted to $\mathrm{pH}=5$ using sulfuric acid. Each solution was illuminated in an RPR-200 photoreactor system (George et al., 2015) until approximately half of the initial phenol was degraded (as monitored by a high-performance liquid chromatograph (HPLC) with a UVvisible detector). At that point, $12.0 \mathrm{~mL}$ of the illuminated solution was placed in an aluminum cup and blown gently to dryness with pure $\mathrm{N}_{2}$ at room temperature. Another aliquot of the illuminated solution was flash frozen with liquid nitrogen and stored at $-20^{\circ} \mathrm{C}$ in the dark until analysis. Note that the flash-frozen samples contain dissolved volatile species, low-volatility species, and unreacted precursors, while the blown-down samples are composed of only low-volatility species. Indeed, HPLC analysis of the blown-down samples detected negligible amounts of the initial phenols, indicating that they were completely removed. In addition, all phenolic precursors show first-order decay during photoreactions to a time of one half-life (Smith et al., 2014), indicating that the reaction intermediates or products are not acting as significant photosensitizers. The phenol precursors themselves are not effective photosensitizers since they have little or no light absorption in the solar range (Smith et al., 2014). Dark control experiments, carried out under the same conditions except in the dark, showed negligible loss of phenol and no formation of aqSOA. In addition, no formation of aqSOA was observed in control experiments in which 3,4-DMB was illuminated alone under the same conditions and the resulting solution evaporated in the same way.

\subsection{Analytical methods}

\subsubsection{Aerosol mass spectrometry (AMS) measurement and data analysis}

In this study, a high-resolution time-of-flight aerosol mass spectrometer (Aerodyne Res. Inc., Billerica, MA; there- 
Table 1. Summary of the chemical characteristics of phenolic aqSOA formed under different experimental conditions.

\begin{tabular}{|c|c|c|c|c|c|c|c|c|c|c|c|c|c|}
\hline \multicolumn{3}{|c|}{ Sample information } & \multicolumn{6}{|c|}{ AMS results } & \multicolumn{3}{|c|}{ Nano-DESI MS results } & \multirow{2}{*}{$\begin{array}{c}\mathrm{IC} \\
\text { results } \\
\text { Organic } \\
\text { acids } \\
(\% \text { of } \\
\text { TOC })^{\mathrm{f}} \\
\end{array}$} & \multirow{2}{*}{$\begin{array}{c}\text { TOC results } \\
\begin{array}{c}\text { Dissolved } \\
\text { volatile } \\
\text { species }^{\mathrm{g}}(\%)\end{array}\end{array}$} \\
\hline Precursor & Oxidant & $\begin{array}{c}\mathrm{t}_{1 / 2}{ }^{\mathrm{a}} \\
(\mathrm{min})\end{array}$ & $\mathrm{OM} / \mathrm{OC}$ & $\mathrm{O} / \mathrm{C}$ & $\mathrm{H} / \mathrm{C}$ & $\mathrm{OS}_{\mathrm{C}}^{\mathrm{b}}$ & $\begin{array}{r}\Sigma m / z \\
\geq 80^{\mathrm{c}} \\
(\%)\end{array}$ & $\begin{array}{c}\text { Dimer }^{\mathrm{d}} \\
(\%)\end{array}$ & $\begin{array}{c}\# \text { of } \\
\text { molecules }\end{array}$ & $\begin{array}{r}\# \text { of } \\
\mathrm{m}\end{array}$ & $\begin{array}{l}\text { common } \\
\text { lecules }\end{array}$ & & \\
\hline \multirow{2}{*}{$\begin{array}{c}\text { Syringol } \\
\left(\mathrm{C}_{8} \mathrm{H}_{10} \mathrm{O}_{3}\right) \\
\mathrm{H}_{3} \mathrm{CO} \mathrm{OH}_{3} \mathrm{OCH}_{3}\end{array}$} & ${ }^{3} \mathrm{C}^{*}$ & 16 & 2.29 & 0.85 & 1.66 & 0.04 & 13.3 & - & 1156 & \multirow{2}{*}{\multicolumn{2}{|c|}{883}} & 0.8 & 6.6 \\
\hline & $\bullet \mathrm{OH}$ & 45 & 2.27 & 0.86 & 1.64 & 0.08 & 12.3 & - & 998 & & & 0.7 & 5.9 \\
\hline \multirow[t]{2}{*}{$\begin{array}{c}\text { Guaiacol } \\
\left(\mathrm{C}_{7} \mathrm{H}_{8} \mathrm{O}_{2}\right) \\
\text { OH }\end{array}$} & ${ }^{3} \mathrm{C}^{*}$ & 35 & 2.37 & 0.92 & 1.79 & 0.05 & 14.7 & 0.70 & 827 & \multirow{2}{*}{643} & \multirow{4}{*}{149} & 0.8 & 4.6 \\
\hline & $\cdot \mathrm{OH}$ & 160 & 2.72 & 1.18 & 1.85 & 0.51 & 9.8 & 0.15 & 871 & & & 2.2 & 2.7 \\
\hline \multirow{2}{*}{$\begin{array}{c}\text { Phenol } \\
\left(\mathrm{C}_{6} \mathrm{H}_{6} \mathrm{O}\right) \\
\mathrm{OH}\end{array}$} & ${ }^{3} \mathrm{C}^{*}$ & 480 & 2.63 & 1.11 & 1.70 & 0.52 & 8.8 & 0.51 & 721 & \multirow{2}{*}{209} & & 2.1 & 2.8 \\
\hline & $\cdot \mathrm{OH}$ & 672 & 2.79 & 1.23 & 1.72 & 0.74 & 6.8 & 0.01 & 445 & & & 3.8 & 5.7 \\
\hline
\end{tabular}

\footnotetext{
${ }^{\mathrm{a}} t_{1 / 2}$ is the time when approximately half of the phenolic precursor had been reacted (as monitored by HPLC with a UV-vis detector.).

${ }^{\mathrm{b}} \mathrm{OS}_{C}$ indicates the oxidation state of the carbon atom $(=2 \times \mathrm{O} / \mathrm{C}-\mathrm{H} / \mathrm{C})$.

c $\%$ of total ion signal at $m / z \geq 80$ in the AMS spectra.

$\mathrm{d}$ estimated based on the signal contribution of the molecular ions of the dimers in the AMS spectra and the NIST spectra. NIST spectrum of syringol dimer is not available.

$\mathrm{e}$ total number of molecules identified in the $(+)$ ion mode and (-) ion mode nano-DESI MS spectra.

f $\%$ of organic carbon mass in aqSOA accounted for by the sum of eight organic acids (formate, acetate, pyruvate, malate, oxalate, malonate, fumarate, and maleate).

$\mathrm{g}$ dissolved volatile species is calculated as the differences in TOC between flash-frozen and blown-down samples after correction for the mass of unreacted precursors.
}

inafter referred to as AMS) was used to characterize the bulk chemical composition and elemental ratios of the lowvolatility substances in both blown-down and flash-frozen samples. The working principles of the AMS have been discussed previously (DeCarlo et al., 2006; Canagaratna et al., 2007). Briefly, the AMS analyzes non-refractory aerosols that evaporate at $\sim 600^{\circ} \mathrm{C}$ under high vacuum via $70 \mathrm{eV}$ EI mass spectrometry. In this study, the AMS was operated alternatively between "V" and "W" ion optical modes (mass resolutions of $\sim 3000$ and $\sim 5000$, respectively) to acquire mass spectra up to $m / z 500$ and $m / z 300$, respectively. Prior to AMS analysis, each blown-down sample was dissolved in $6.0 \mathrm{~mL}$ Milli-Q water and the flash-frozen samples were thawed overnight inside a refrigerator $\left(\sim 4^{\circ} \mathrm{C}\right)$. The liquid samples were atomized in argon (industrial grade, $99.997 \%$ ) using a constant output atomizer coupled with a diffusion dryer and the resulting particles were analyzed by the AMS downstream of a digitally controlled thermodenuder (TD) (Fierz et al., 2007). The TD consists of a bypass line and a heated line terminating in a section with activated carbon cloth. The temperature inside the heated line was programmed to cycle through seven different temperatures (25, $40,65,85,100,150$, and $200^{\circ} \mathrm{C}$ ) every hour. An automated three-way valve switched the sample flow between bypass and TD modes every $5 \mathrm{~min}$. By comparing the measurements between these two modes, we can determine the volatility profiles of the aqSOA. Between every two sample runs, Milli-Q water was atomized and analyzed as an analytical blank.
The AMS data were analyzed using the AMS data analysis software (SQUIRREL v1.12 and PIKA v1.53 downloaded from http://cires.colorado.edu/jimenez-group/ ToFAMSResources/ToFSoftware/). The W-mode data was analyzed to determine the atomic ratios of oxygen-to-carbon $(\mathrm{O} / \mathrm{C})$ and hydrogen-to-carbon $(\mathrm{H} / \mathrm{C})$ and the organicmass-to-organic-carbon ratio (OM / OC) of phenolic aqSOA (Aiken et al., 2008). V-mode data were analyzed for information of higher molecular weight ions with $m / z>300$, such as syringol dimer $\mathrm{C}_{16} \mathrm{H}_{18} \mathrm{O}_{6}^{+}(\mathrm{m} / z$ 306) and guaiacol trimer $\mathrm{C}_{21} \mathrm{H}_{20} \mathrm{O}_{6}^{+}(m / z 368)$. Note that accurately quantifying the organic contributions to the $\mathrm{H}_{2} \mathrm{O}^{+}, \mathrm{CO}^{+}$, and $\mathrm{CO}_{2}^{+}$signals in an ensemble mass spectrum is critical to the determination of the $\mathrm{O} / \mathrm{C}$ and $\mathrm{H} / \mathrm{C}$ ratios of an organic aerosol (Aiken et al., 2008; Sun et al., 2009; Collier and Zhang, 2013). Since Ar was used as the carrier gas for atomization, $\mathrm{N}_{2}$ and $\mathrm{CO}_{2}$ did not interfere with the quantification of the organic $\mathrm{CO}^{+}$and $\mathrm{CO}_{2}^{+}$signals. In terms of the $\mathrm{H}_{2} \mathrm{O}^{+}$signal, contribution from gaseous water molecules was negligible because the relative humidity measured at the AMS inlet was very low $(<2 \%)$. In addition, since heating the aerosol to $40^{\circ} \mathrm{C}$ prior to AMS sampling led to almost no change in the relative intensities of the $\mathrm{H}_{2} \mathrm{O}^{+}$signal in the mass spectra of aqSOA (Fig. S1 in the Supplement), particles appeared to be completely dry. The organic portion of the $\mathrm{H}_{2} \mathrm{O}^{+}$signal was thus determined as the difference between the measured $\mathrm{H}_{2} \mathrm{O}^{+}$signal and the sulfate-associated $\mathrm{H}_{2} \mathrm{O}^{+}$signal estimated according to the known fragmentation pattern of sulfates (Allan et al., 2004). 


\subsubsection{Nanospray desorption electrospray ionization mass spectrometry (nano-DESI MS) measurement and data analysis}

Prior to nano-DESI MS analysis, the blown-down samples of phenolic aqSOA were dissolved in Milli-Q water, atomized, and collected on Teflon membrane filters. The analyses were performed using a high-resolution LTQ-Orbitrap mass spectrometer (Thermo Electron, Bremen, Germany) with a resolving power $(m / \Delta m)$ of 100000 at $m / z=400$. The instrument is equipped with a nano-DESI source assembled from two fused-silica capillaries $(150 \mu \mathrm{m}$ outer diameter $/ 50 \mu \mathrm{m}$ inner diameter) (Roach et al., 2010b). Analyte molecules extracted into the liquid bridge formed between the two capillaries are transferred to a mass spectrometer inlet and ionized by nanoelectrospray. The analysis was performed under the following conditions: spray voltage of 3-5 $\mathrm{kV}, 0.5-1 \mathrm{~mm}$ distance from the tip of the nanospray capillary to the $300^{\circ} \mathrm{C}$ heated inlet of the LTQ-Orbitrap, and $0.3-0.9 \mu \mathrm{L} \mathrm{min}^{-1}$ flow rate of acetonitrile : water $(1: 1 \mathrm{vol}-$ ume) solvent. The instrument was calibrated using a standard mixture of caffeine, MRFA (Met-Arg-Phe-Ala) peptide, and Ultramark 1621 (Thermo Scientific, Inc.) for the positive ion mode and a standard mixture containing sodium dodecyl sulfate, sodium taurocholate, and Ultramark 1621 (Thermo Scientific, Inc.) for the negative ion mode. Both positive- and negative-mode mass spectra were acquired using the Xcalibur software (Thermo Electron, Inc.). To analyze a sample, the nano-DESI probe was first placed on a clean area of the filter to record the background signal for $\sim 3 \mathrm{~min}$ and then positioned on the sample region to acquire data for an additional 4-5 min (Roach et al., 2010a).

Peaks with a $\mathrm{S} / \mathrm{N}$ (signal-to-noise ratio) $>10$ were selected using the Decon2LS software developed at the Pacific Northwest National Laboratory (PNNL) (Jaitly et al., 2009). Further data processing was performed with Microsoft Excel using a set of built-in macros developed by Roach et al. (2011). The background and sample peaks were aligned, and the peaks corresponding to ${ }^{13} \mathrm{C}$ isotopes were removed. Only peaks in the sample spectra that are at least 10 times bigger than the corresponding peaks in the background spectra were retained for further analysis. Peaks were segregated into different groups using the higher-order mass defect transformation developed by Roach et al. (2011). Specifically, the peaks were first grouped using a $\mathrm{CH}_{2}$-based transformation and then an $\mathrm{H}_{2}$-based second-order transformation. Formula Calculator v. 1.1 (http://www.magnet.fsu.edu/ usershub/scientificdivisions/icr/icr_software.html) was then used to assign the molecular formula to each group using the following constraints: $\mathrm{C} \geq 0, \mathrm{H} \geq 0, \mathrm{O} \geq 0$ for the negative ion mode data and $\mathrm{C} \geq 0, \mathrm{H} \geq 0, \mathrm{O} \geq 0, \mathrm{Na} \leq 1$ for the positive ion mode data. Approximately $70 \%$ of the peaks were assigned with molecular formula within these constraints. The formulas of neutral species were subsequently determined by removing the adduct ion (e.g., a proton or a sodium ion) from the positive ions or by adding a proton to the negative ions.

Kendrick representation of high-resolution mass spectral data can be used to search for potential oligomeric units (Hughey et al., 2001). In this study, O-based Kendrick diagram was used to investigate the degree of hydroxylation. The Kendrick mass (KM) and Kendrick mass defect (KMD) are calculated using the following two equations:

$\mathrm{KM}=$ observed mass $\times 16 / 15.9949$,

$\mathrm{KMD}=\mathrm{NM}-\mathrm{KM}$,

where 16 is the nominal mass of $\mathrm{O}, 15.9949$ is the exact mass of the $\mathrm{O}$, and $\mathrm{NM}$ is the $\mathrm{KM}$ rounded to the nearest integer. Plotting KMD versus KM reveals homologous series of compounds differing only by the number of base units which fall on horizontal lines.

Double bond equivalent (DBE) indicates the number of double bonds and rings in a closed-shell organic molecule (Pellegrin, 1983). For a molecule with a nominal formula of $\mathrm{C}_{\mathrm{x}} \mathrm{H}_{\mathrm{y}} \mathrm{O}_{\mathrm{z}}$ (where $x, y, z$ denote the number of $\mathrm{C}, \mathrm{H}$, and $\mathrm{O}$ atoms, respectively, in the molecule), $\mathrm{DBE}=1-y / 2+x$.

\subsubsection{Ion chromatography (IC) and total organic carbon (TOC) analysis}

Concentrations of inorganic/organic anions were measured using an ion chromatograph (Metrohm 881 Compact IC Pro, Switzerland) equipped with an autosampler, a Metrosep RP2 guard/3.6 column and a Metrosep A Supp15 250/4.0 column, and a conductivity detector. Details on the IC method are given in Ge et al. (2014). Briefly, anions were eluted at $0.8 \mathrm{ml} \mathrm{min}^{-1}$ using an eluent of $5 \mathrm{mmol} \mathrm{L}^{-1} \mathrm{Na}_{2} \mathrm{CO}_{3}$ and $0.3 \mathrm{mmol} \mathrm{L}^{-1} \mathrm{NaOH}$ in water. This method can separate and quantify nine organic anions (glycolate, formate, acetate, pyruvate, oxalate, malate, malonate, maleate, and fumarate) and seven inorganic anions $\left(\mathrm{F}^{-}, \mathrm{Cl}^{-}, \mathrm{NO}_{2}^{-}, \mathrm{Br}^{-}\right.$, $\mathrm{NO}_{3}^{-}, \mathrm{SO}_{4}^{2-}$ and $\mathrm{PO}_{4}^{3-}$ ). The IC results were evaluated in terms of reproducibilities of retention times and peak heights and linearity of the calibration curves. Analysis of external check standards, including a seven-anion standard mixture (Dionex) and four individual standards (Metrohm), always produced results that were within $10 \%$ of certified values. Relative differences for replicate analyses were within $3 \%$.

A Shimadzu TOC-VCPH analyzer was applied to measure TOC in the aqSOA samples. The instrument uses a combustion tube filled with oxidation catalyst to convert all carbon atoms into $\mathrm{CO}_{2}$ at $720^{\circ} \mathrm{C}$ under ultra-pure air and quantifies the resulting $\mathrm{CO}_{2}$ using a non-dispersive infrared (NDIR) analyzer. Prior to combustion, inorganic carbon species (carbonates/bicarbonates and dissolved $\mathrm{CO}_{2}$ ) is transformed into $\mathrm{CO}_{2}$ by $25 \% \mathrm{H}_{3} \mathrm{PO}_{4}$, bubbled out, and determined by NDIR. TOC is determined as the difference. The TOC analyzer was calibrated using the standard solutions of $\mathrm{NaHCO}_{3}, \mathrm{Na}_{2} \mathrm{CO}_{3}$, and potassium hydrogen phthalate (Sigma-Aldrich or Wako- 


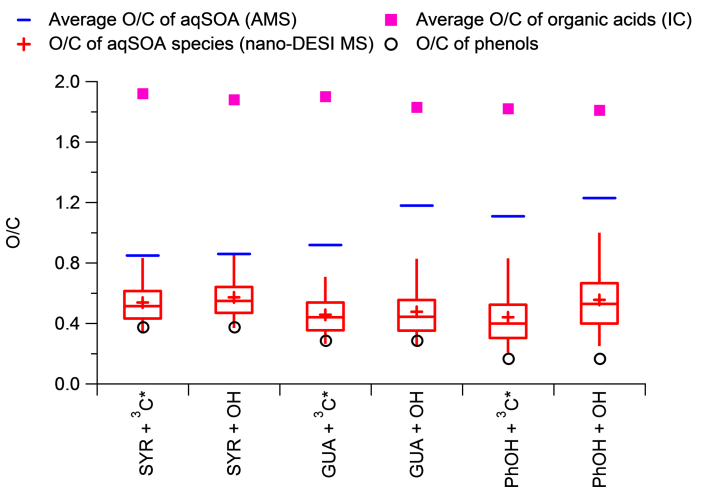

Figure 1. The average $\mathrm{O} / \mathrm{C}$ ratios of aqSOA formed from the reactions of syringol (SYR), guaiacol (GUA), and phenol (PhOH) with ${ }^{3} \mathrm{C}^{*}$ and $\cdot \mathrm{OH}$, respectively determined by AMS (blue bars) and the average $\mathrm{O} / \mathrm{C}$ of organic acids determined by IC (pink squares). The distributions of the $\mathrm{O} / \mathrm{C}$ of individual molecules in the aqSOA determined by nano-DESI MS are shown in box plots, in which the whiskers above and below the boxes indicate the 95th and 5th percentiles, the upper and lower boundaries of the boxes indicate the 75th and 25th percentiles, and the lines in the boxes indicate the median values and the cross symbols indicate the mean values. The $\mathrm{O} / \mathrm{C}$ of the precursors are shown as black circles.

Japan, $\geq 99.0 \%$ ). Results from external TOC check standards (Aqua Solutions) were always within $10 \%$ of certified values.

\section{Results and discussion}

\subsection{Overview of the chemical characteristics of phenolic aqSOA}

The lifetime of phenols with respect to ${ }^{3} \mathrm{C}^{*}$ and $\cdot \mathrm{OH}$ reactions in atmospheric fog and cloud water is on the order of minutes to hours during daytime (Smith et al., 2014). Compared to $\cdot \mathrm{OH},{ }^{3} \mathrm{C}^{*}$ reacts more quickly with phenols, but the mass yields of aqSOA from both reactions are near $100 \%$ for phenol, guaiacol, and syringol (Smith et al., 2014). The reaction rate comparisons in this manuscript are based on the experimentally measured pseudo-first-order rate constants for phenol loss $\left(k_{\mathrm{ArOH}}^{\prime}\right)$, which are equal to the product of the bimolecular rate constant and steady-state concentration of oxidant: $k^{\prime} \mathrm{ArOH}=k_{\mathrm{ArOH}}+$ Oxidant $[$ Oxidant] (Smith et al., 2014). Based on bimolecular rate constants determined by Smith et al. (in preparation), the steady-state concentrations of $\cdot \mathrm{OH}$ and ${ }^{3} \mathrm{C}^{*}$ during this study are estimated at $10^{-16}$ $10^{-15} \mathrm{~mol} \mathrm{~L}^{-1}$ and at $10^{-14} \mathrm{~mol} \mathrm{~L}^{-1}$, respectively, which are similar to the typical aqueous $\cdot \mathrm{OH}$ concentration in fog and cloud waters (Anastasio and McGregor, 2001; Arakaki et al., 2013) and the ${ }^{3} C^{*}$ concentration measured in Davis fog waters (R. Kaur, unpublished results).

As shown in Fig. 1 and summarized in Table 1, the aqSOA formed from all three phenols with both oxidants are highly oxygenated, with average $\mathrm{O} / \mathrm{C}$ ratios in the range of 0.85 1.23 and average $\mathrm{OM} / \mathrm{OC}$ in the range of 2.27-2.79. Based on a comparison to the $\mathrm{OM} / \mathrm{OC}$ of the precursors, the mass yields of the aqSOA should be $142-214 \%$, assuming all reacted phenols were converted into low-volatility species. However, the measured values are 16-38\% lower, indicating that approximately $16-38 \%$ of the reacted phenols were converted into volatile and semi-volatile species that evaporated during illumination and/or drying. These results are consistent with a previous study by Sun et al. (2010), where O / C ratios of phenolic aqSOA formed from direct photodegradation and $\cdot \mathrm{OH}$ oxidation were in the range of $0.80-1.06$. The $\mathrm{O} / \mathrm{C}$ of phenolic SOA from gas-phase $\cdot \mathrm{OH}$ oxidation are also near unity (Chhabra et al., 2011; Yee et al., 2013). Due to high oxygen contents, the OM / OC ratios of the aqSOA are high (average $=2.27-2.79$; Table 1). Note that the OM / OC ratios determined by AMS agree well with those determined based on aqSOA mass measured gravimetrically and organic carbon mass measured by a TOC analyzer (Fig. S2 in the Supplement). For the same oxidant, the $\mathrm{O} / \mathrm{C}$ ratio of the aqSOA formed at $t_{1 / 2}$ follows the order: phenol $>$ guaiacol $>$ syringol (Table 1). This trend is likely driven by precursor reactivity, which determines how long the solution needed to be illuminated to reach one half-life, and has the order: syringol $>$ guaiacol $>$ phenol. The reactivity differences among the three precursors are likely due to the electron-donating effect of the o-methoxy substituents, which may increase the rate of electrophilic reactions on the benzene ring. Longer illumination time increases the formation of highly oxygenated species and ring-opening species $\left(\mathrm{n}_{\mathrm{C}}<6\right)$. For the same reason, $\cdot \mathrm{OH}$ oxidation, which is slower than ${ }^{3} \mathrm{C}^{*}$ reaction for the same phenol precursor, generally produces more oxidized aqSOA at $t_{1 / 2}$

Figures S3 and S4 in the Supplement show the nano-DESI MS spectra of the aqSOA of syringol, guaiacol, and phenol formed from ${ }^{3} \mathrm{C}^{*}$ and $\cdot \mathrm{OH}$ reactions, respectively. Hundreds of species were identified, all of which are oxygenated with the median $\mathrm{O} / \mathrm{C}$ ratios of the molecules varying from 0.33-0.55 in different aqSOA (Fig. 1). The signal-weighted average $\mathrm{O} / \mathrm{C}$ ratios (Bateman et al., 2012) of phenolic aqSOA are in the range of $0.31-0.65$ according to the negative ion mode nano-DESI results, which are systematically lower than the average $\mathrm{O} / \mathrm{C}$ of bulk aqSOA measured by the AMS (Fig. 1). However, due to large differences between the AMS and the nano-DESI methodology, in terms of sample analysis, data processing, and assumptions used for average $\mathrm{O} / \mathrm{C}$ calculations, a direct comparison between these two sets of $\mathrm{O} / \mathrm{C}$ data should be cautioned.

Figure 2 shows the AMS spectra of different aqSOA acquired after $50 \%$ of the initial phenols had reacted (i.e., at $\left.t_{1 / 2}\right)$. A prominent feature of these spectra is that $\mathrm{CO}_{2}^{+}(m / z=44), \mathrm{H}_{2} \mathrm{O}^{+}(m / z=18)$, and $\mathrm{CO}^{+}(m / z=28)$ are the largest peaks, similar to the spectral pattern of fulvic acid - a model compound representative of highly processed and oxidized organic particulate matter and humic- 


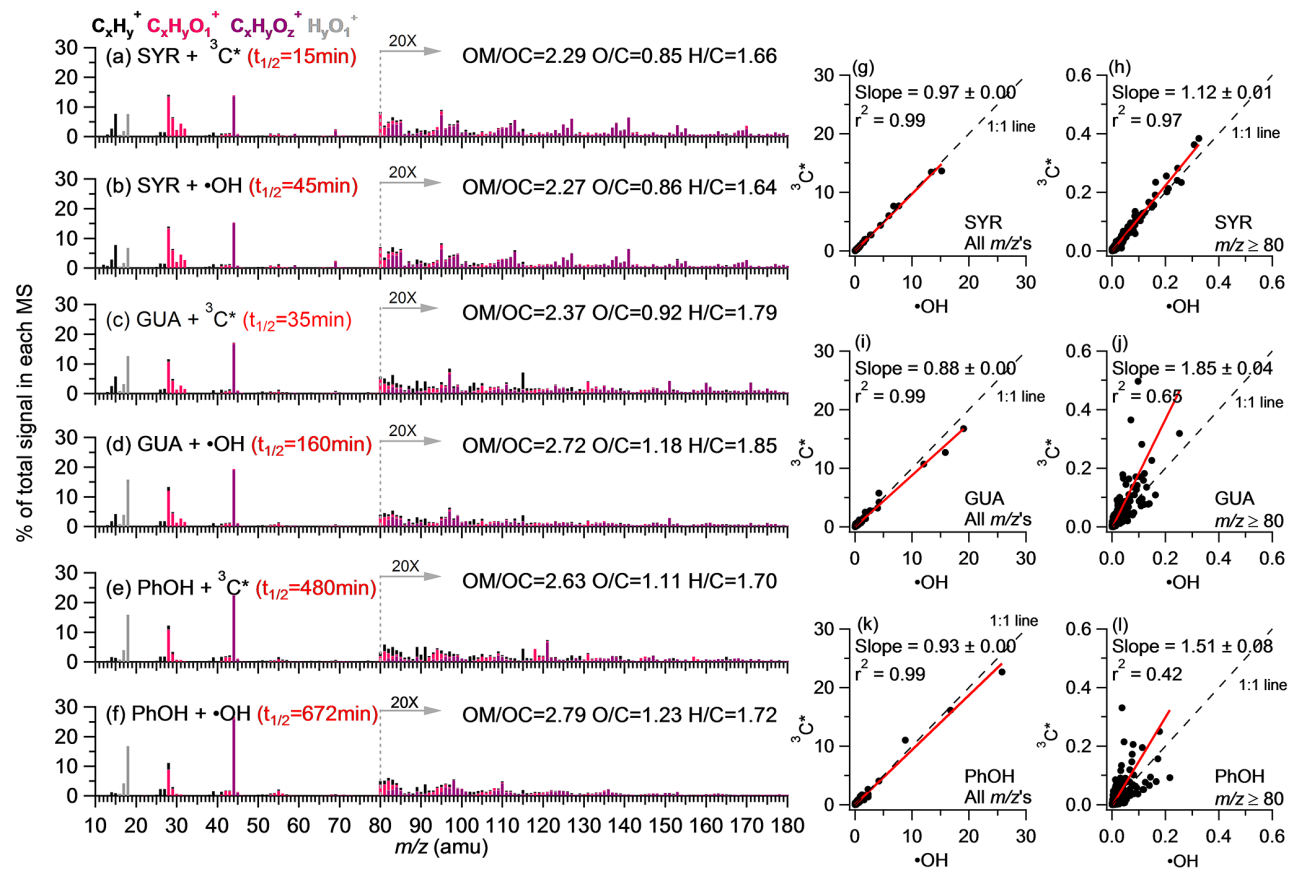

Figure 2. AMS spectra of aqSOA formed from the reactions of (a-b) syringol (SYR), (c-d) guaiacol (GUA), and (e-f) phenol (PhOH) with ${ }^{3} \mathrm{C}^{*}$ and $\cdot \mathrm{OH}$, respectively. The peaks are color-coded according to four ion categories: $\mathrm{C}_{\mathrm{x}} \mathrm{H}_{\mathrm{y}}^{+}, \mathrm{C}_{\mathrm{x}} \mathrm{H}_{\mathrm{y}} \mathrm{O}_{1}^{+}, \mathrm{C}_{\mathrm{x}} \mathrm{H}_{\mathrm{y}} \mathrm{O}_{\mathrm{z}}^{+}$, and $\mathrm{H}_{\mathrm{y}} \mathrm{O}_{1}^{+}(x \geq 1$; $y \geq 0 ; z \geq 2$ ). The ion signals at $m / z \geq 80$ are enhanced by a factor of 20 for clarity. The photoreaction time and the elemental ratios of the aqSOA are shown in the legends. Scatter plots that compare the mass spectra of aqSOA formed from two different oxidants for all $m / z$ 's (g, $\mathbf{i}, \mathbf{k})$ and for $m / z \geq 80(\mathbf{h}, \mathbf{j}, \mathbf{l})$ were performed using the orthogonal distance regression (ODR). The linear regression slopes and correlation coefficients are shown in the legends.

like substances (HULIS) (Zhang et al., 2005; Ofner et al., 2011). The AMS spectra of syringol aqSOA formed from different oxidants are almost identical (Fig. 2), indicating similar chemical compositions. Similarly, nano-DESI analysis shows the formation of a large number of common species, i.e., 883 species with common elemental composition (Table 1), through the reactions of syringol with ${ }^{3} \mathrm{C}^{*}$ and $\cdot \mathrm{OH}$, which account for 76 and $88 \%$, respectively, of the total number of molecules identified in the corresponding aqSOA. A similar overlap of common species was observed for guaiacol aqSOA. However, the molecular compositions of phenol aqSOA show a greater difference between the two oxidants (Table 1), which is consistent with the fact that the AMS spectra of the two phenol aqSOA are largely different at $m / z \geq 80$ (Fig. 21). The more distinct compositional differences of phenol aqSOA between the $\cdot \mathrm{OH}$ and ${ }^{3} \mathrm{C}^{*}$ reactions is probably due to the larger difference in reaction times (i.e., $t_{1 / 2}=672 \mathrm{~min}$ vs. $480 \mathrm{~min}$; Table 1). Detailed discussions on the comparisons of aqSOA produced from the same precursor but different oxidants are given in Sect. 3.3.

A total number of 149 common molecules were identified in all samples (Table 1). Figure 3 shows the van Krevelen diagram of these common molecules. A majority of these molecules have molecular weight lower than $400 \mathrm{Da}$ and DBE $<12$ (Fig. 3), indicating that they contain two or
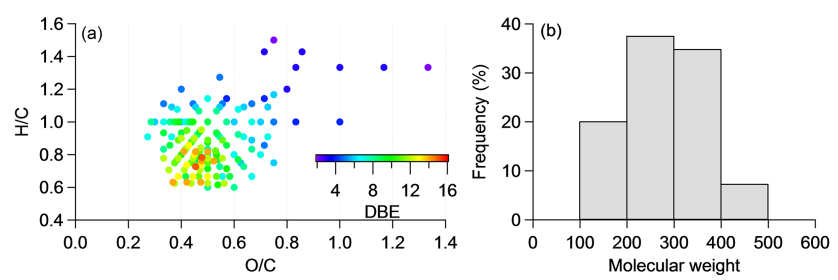

Figure 3. (a) Van Krevelen diagram of common molecules identified in every phenolic aqSOA via nano-DESI MS analysis. Each data point is colored by its DBE value. (b) A frequency histogram of the molecular weight of these common molecules.

less aromatic rings and that they were likely produced from ring-opening reactions. In addition, small carboxylate anions were observed in all aqSOA samples, although they represent only a small fraction of the TOC (Table 1). It is interesting to point out that the number of molecules observed by nano-DESI decreases with increasing illumination time across all three phenols, suggesting that increased aging simplifies the products to a smaller set (Table 1). However, this trend could also be related to ionization efficiency of different types of phenolic aqSOA. For example, syringol aqSOA has more methoxy groups, thus more easily ionized by nanoDESI compared to phenol aqSOA. 
Table 2. Top 10 most abundant compounds in syringol SOA formed in ${ }^{3} \mathrm{C}^{*}$-mediated and $\cdot \mathrm{OH}$-mediated reactions identified with (-) nano-DESI MS.

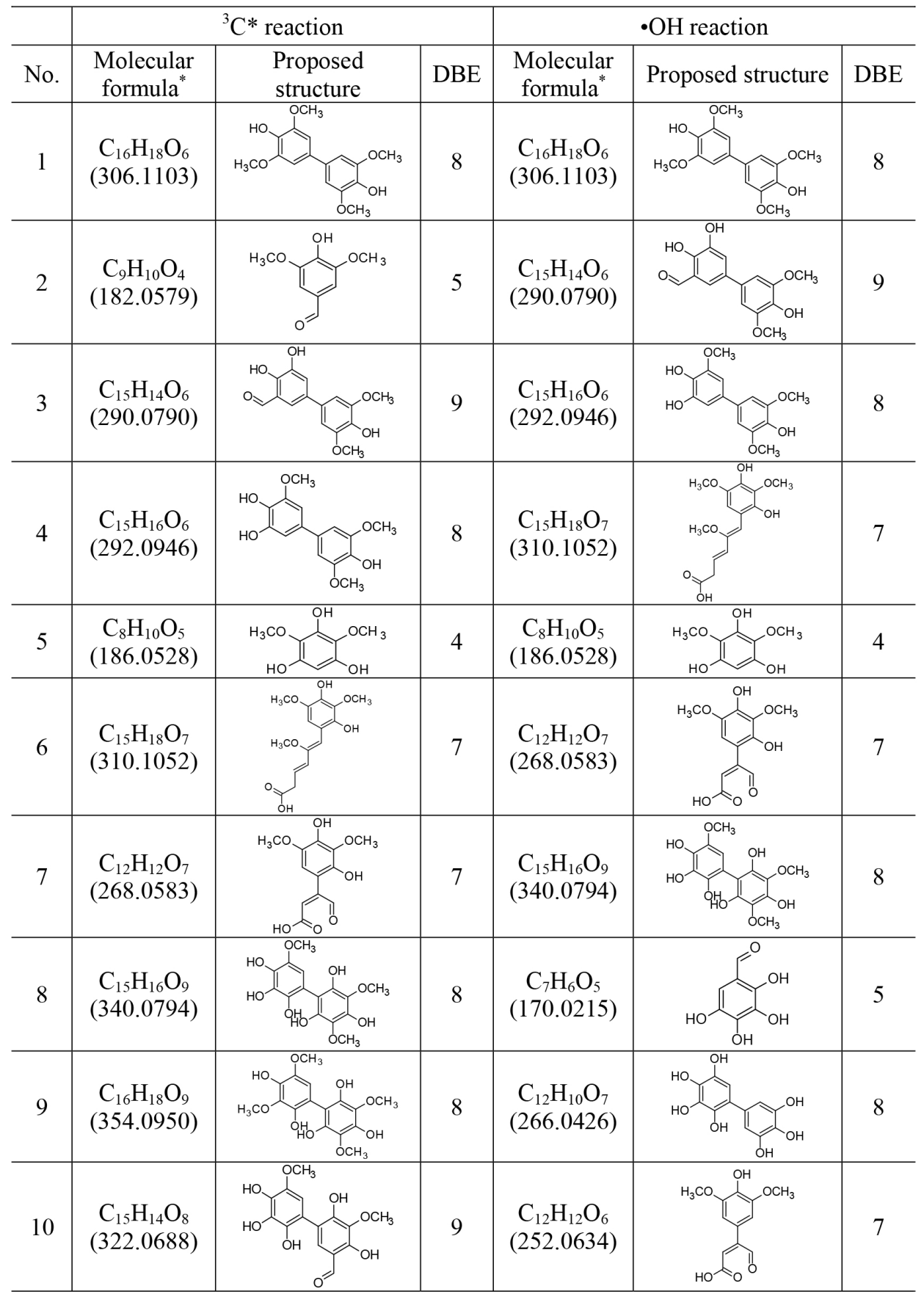

* Molecular formula of top 10 most abundant compounds with their exact mass in the parenthesis.

Both flash-frozen (FF) and blown-down (BD) samples were chemically characterized and show almost identical AMS spectra (Fig. S5). We also found that the electrospray ionization mass spectra of the aqueous solution of the blowndown sample and the flash-frozen sample for the aqSOA formed from syringol $+{ }^{3} \mathrm{C}^{*}$ are also overall similar. These observations confirm that the non-volatile components of these two sample types are chemically very similar, and the blown-down procedure had relatively small influence on the observed product distribution. Since FF samples contain dissolved volatile species which should have evaporated during nebulization and drying, we estimated the amount of these 


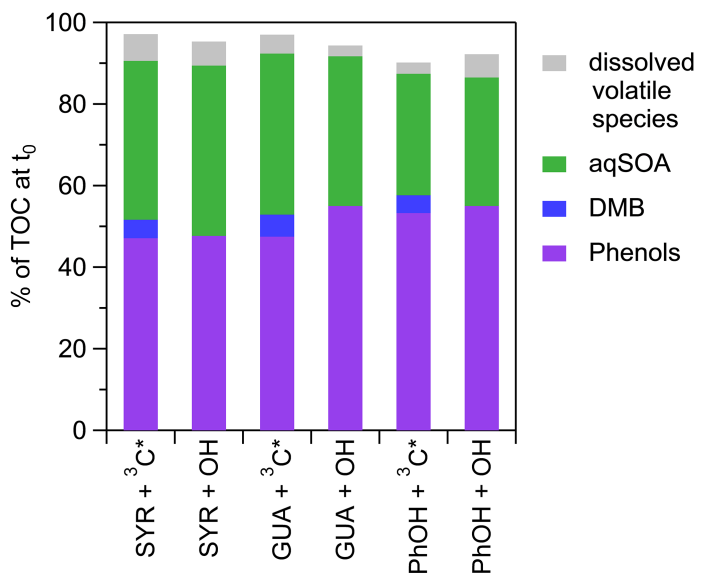

Figure 4. Contributions of reactants (phenolic precursor and DMB) and products (dissolved volatile species and aqSOA) to the solution TOC after illumination to $t_{1 / 2}$. TOC amounts are expressed relative to the TOC in the initial solution prior to illumination (i.e., at $t_{0}$ ).

species by examining the differences in the TOC concentrations between FF and BD samples after correction for the mass of unreacted precursors. Figure 4 shows the contributions of reactants (phenolic precursor and DMB) and products (dissolved volatile species and aqSOA) to the solution TOC after illumination to $t_{1 / 2}$. Dissolved volatile species formed during photolysis represent a small fraction (2.7$6.6 \%$; Table 1) of the total carbon originally present in the reactants, consistent with the high mass yields of phenolic aqSOA reported by Smith et al. (2014).

\subsection{Insights into aqSOA formation mechanisms}

In this section we synthesize the molecular composition and bulk chemistry results and interpret the formation mechanisms of phenolic aqSOA. A notable result is the large number of dimer and higher oligomers (up to hexamer) found in the aqSOA. As shown in Figs. S3 and S4 in the Supplement, the nano-DESI MS spectra of phenolic aqSOA contain clearly distinguished regions corresponding to monomers, dimers, trimers, tetramers, pentamers, and hexamers and their oxidation products. We therefore determine the distributions of phenolic aqSOA species based on the degree of oligomerization by summing signals in each region (Fig. 5). Oligomers and related derivative species clearly account for a significant fraction (24.2-92.6\%) of the total signals in the nano-DESI spectra of all phenolic aqSOA. Substituted monomers and ring-opening species $\left(\mathrm{n}_{\mathrm{C}}<6\right)$ are also present in all aqSOA and they are particularly abundant in that of phenol $+\cdot \mathrm{OH}$.

Table 2 lists the 10 most abundant compounds identified in the aqSOA of syringol formed through reaction with . $\mathrm{OH}$ or ${ }^{3} \mathrm{C}^{*}$. Among them, seven are common species, including syringol dimer $\left(\mathrm{C}_{16} \mathrm{H}_{18} \mathrm{O}_{6}\right)$, hydroxylated syringol $\left(\mathrm{C}_{8} \mathrm{H}_{10} \mathrm{O}_{5}\right)$, three dimer derivatives $\left(\mathrm{C}_{15} \mathrm{H}_{14} \mathrm{O}_{6}, \mathrm{C}_{15} \mathrm{H}_{16} \mathrm{O}_{6}\right.$

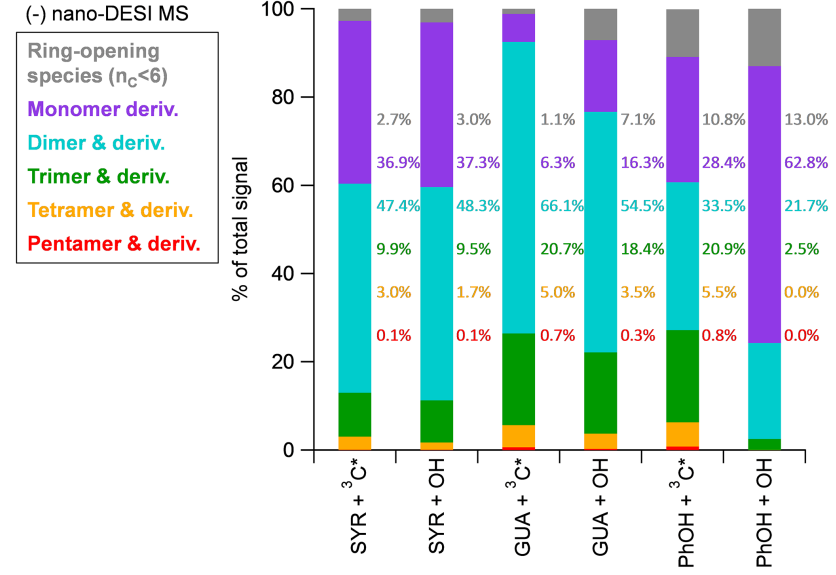

Figure 5. The signal-weighted distributions of syringol (SYR), guaiacol (GUA), and phenol ( $\mathrm{PhOH})$ aqSOA formed in ${ }^{3} \mathrm{C}^{*}$-mediated and $\cdot \mathrm{OH}$-mediated reactions, respectively, based on the degree of oligomerization. The data are from the (-) nano-DESI MS spectra. Note that hexamer and derivatives are only found in $(+)$ nano-DESI MS spectrum for GUA aqSOA initiated with ${ }^{3} \mathrm{C}^{*}$ and (-) nanoDESI MS spectrum for $\mathrm{PhOH}$ aqSOA initiated with ${ }^{3} \mathrm{C}^{*}$. The numbers indicate the contributions of individual categories to the total signals for each sample.

and $\left.\mathrm{C}_{15} \mathrm{H}_{16} \mathrm{O}_{9}\right)$, and two monomer derivatives $\left(\mathrm{C}_{15} \mathrm{H}_{18} \mathrm{O}_{7}\right.$ and $\mathrm{C}_{12} \mathrm{H}_{12} \mathrm{O}_{7}$ ). Guaiacol aqSOA is also dominated by the dimer and related species whereas substituted monomers are more abundant in phenol aqSOA (Fig. 5). The presence of dimers and substituted monomers is also evident in the AMS spectra. As an example, Figure 6 shows the AMS spectra of phenol aqSOA along with the National Institute of Standards and Technology (NIST) mass spectra of possible products. The spectra of guaiacol and syringol aqSOA are shown in Figs. S6 and S7 in the Supplement. Note that the AMS spectrum of biphenyl-4,4'-diol - a substituted phenolic compound - is very similar to the NIST mass spectrum (Fig. S8 in the Supplement), indicating the validity of interpreting the AMS spectra of phenolic aqSOA based on the NIST spectra of possible products. The AMS spectra of phenol aqSOA show a prominent peak at $m / z=186\left(\mathrm{C}_{12} \mathrm{H}_{10} \mathrm{O}_{2}^{+}\right)$, which is the molecular ion $\left(\mathrm{M}^{+}\right.$.) of phenol dimer (Fig. 6). Similarly, the molecular ion of guaiacol dimer $\left(\mathrm{C}_{14} \mathrm{H}_{14} \mathrm{O}_{4}^{+} ; \mathrm{m} / z=246\right.$; Fig. S6 in the Supplement) is also noticeable in the AMS spectra. These results indicate that oligomerization is an important aqueous-phase reaction pathway that leads to the formation of aqSOA from phenols.

Hydroxylation is another important reaction pathway that forms and transforms phenolic aqSOA. As shown in Fig. S9 in the Supplement, the O-based Kendrick diagram of syringol aqSOA clearly indicates the presence of a large number of species with different degrees of hydroxylation. Similarly, AMS analysis reveals the ubiquitous formation of hydroxylated products as well. For example, the AMS spectra of phenol aqSOA show prominent peaks at $m / z=110$ 


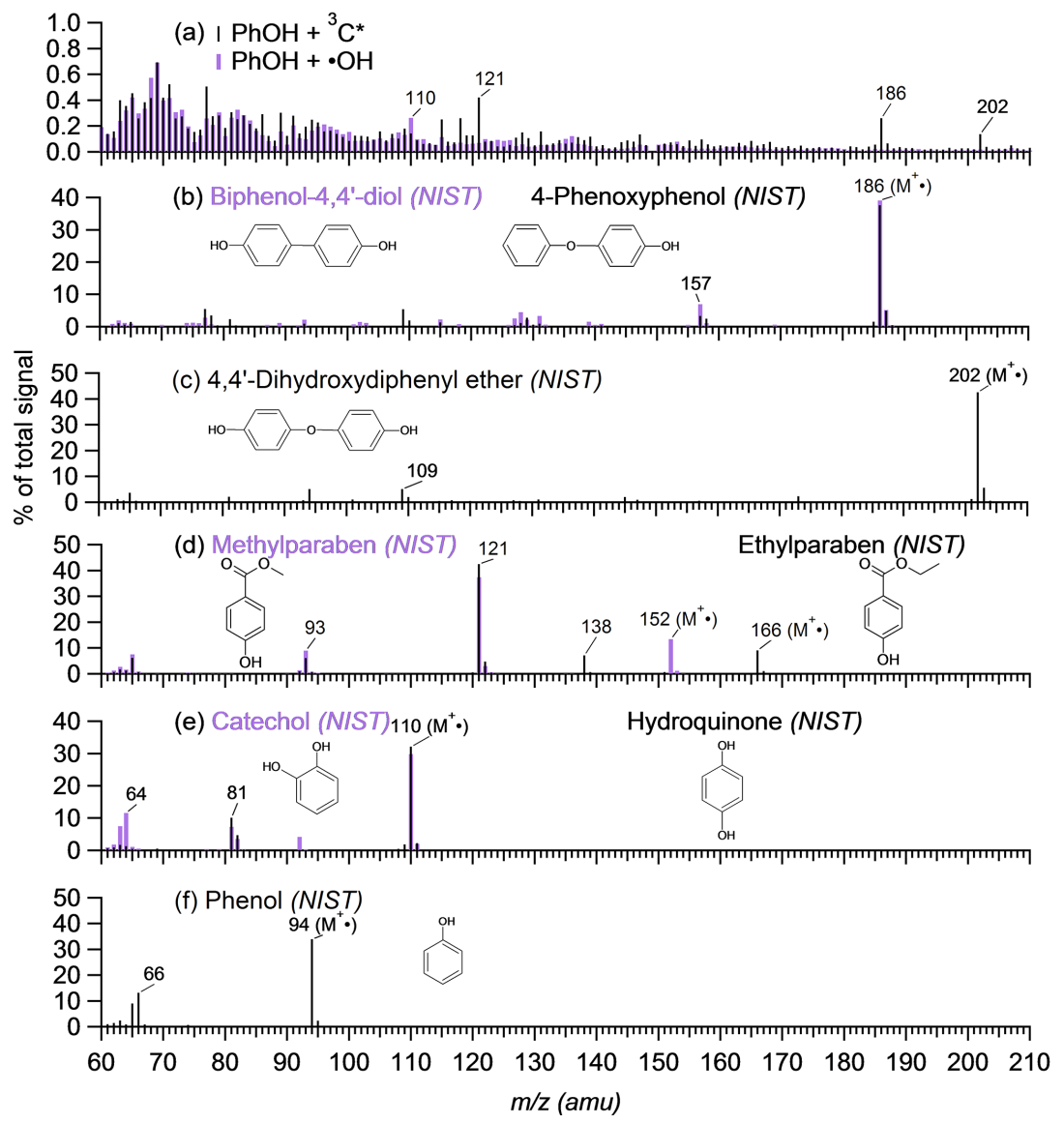

Figure 6. Comparisons between (a) the AMS mass spectra (in integer $m / z$ ) of phenol $(\mathrm{PhOH})$ aqSOA formed via reactions with ${ }^{3} \mathrm{C}^{*}$ and $\cdot \mathrm{OH}$, respectively, and the NIST mass spectra of (b) biphenol-4,4'-diol and 4-phenoxyphenol, (c) 4,4'-dihydroxydiphenyl ether, (d) methylparaben and ethylparaben, (e) catechol and hydroquinone, and (f) phenol. The chemical structures for each compound are shown and the molecular ions $\left(\mathrm{M}^{+}.\right)$are marked.

$\left(\mathrm{C}_{6} \mathrm{H}_{6} \mathrm{O}_{2}^{+}\right)$and $m / z=202\left(\mathrm{C}_{12} \mathrm{H}_{10} \mathrm{O}_{3}^{+}\right)$, suggesting the presence of hydroxylated phenol and hydroxylated phenol dimer, respectively (Fig. 6). In addition, signature ions representing 2-methoxyhydroquinone are detected in guaiacol aqSOA (Fig. S6 in the Supplement), and 3,4,5-trihydroxy benzoic acid is likely a product of syringol oxidation (Fig. S7 in the Supplement).

Both nano-DESI and AMS results further reveal the broad formation of aldehydes, esters, and carboxylated products. As shown in Table 2, $\mathrm{C}_{9} \mathrm{H}_{10} \mathrm{O}_{4}(\mathrm{MW}=182 ; \mathrm{DBE}=5)$, which was found to present at high abundance in the aqSOA of syringol $+{ }^{3} \mathrm{C}^{*}$, is likely a syringol aldehyde. In addition, the pronounced $\mathrm{C}_{7} \mathrm{H}_{5} \mathrm{O}_{2}^{+}(m / z=121)$ peak in the AMS spectra of phenol aqSOA (Fig. 6a) indicates the formation of phenol esters such as methylparaben and ethylparaben (Fig. 6d) and the prominent $\mathrm{C}_{8} \mathrm{H}_{7} \mathrm{O}_{3}^{+}(\mathrm{m} / z=151)$ signal in the guaiacol aqSOA spectra (Fig. S6a in the Supplement) suggests the formation of a guaiacol ester - methyl vanillate (Fig. S6c in the Supplement).
Small organic acid anions (i.e., formate, acetate, oxalate, malate, malonate, etc.) are observed in all samples and these species together account for less than $4 \%$ of the TOC in aqSOA (Table 1). Note that the importance of organic acids is likely underestimated as IC only quantifies a limited number of low molecular weight aliphatic acids. Nano-DESI analysis further reveals the presence of a number of aromatic compounds with substituted carboxyl groups (e.g., aromatic esters; Fig. S10 in the Supplement) and the formation of highly oxygenated $\mathrm{C}_{3}-\mathrm{C} 5$ aliphatic species in all samples, some of which (e.g., $\mathrm{C}_{3} \mathrm{H}_{4} \mathrm{O}_{4}, \mathrm{C}_{4} \mathrm{H}_{6} \mathrm{O}_{4}$, and $\mathrm{C}_{5} \mathrm{H}_{6} \mathrm{O}_{5}$ ) are likely carboxylic acids based on DBE values. Furthermore, both nano-DESI and AMS analyses identify demethoxylated aromatic products (e.g., $\mathrm{C}_{15} \mathrm{H}_{16} \mathrm{O}_{6}$ and $\mathrm{C}_{15} \mathrm{H}_{16} \mathrm{O}_{9}$ in Table 2). These results together indicate that various fragmentation pathways, such as the cleavage of the aromatic rings and the losses of methoxy $\left(-\mathrm{OCH}_{3}\right)$ groups, are important during the aqueous-phase reactions of phenols.

Based on these results, we propose a scheme in Fig. 7 of the main pathways of aqSOA formation through the re- 


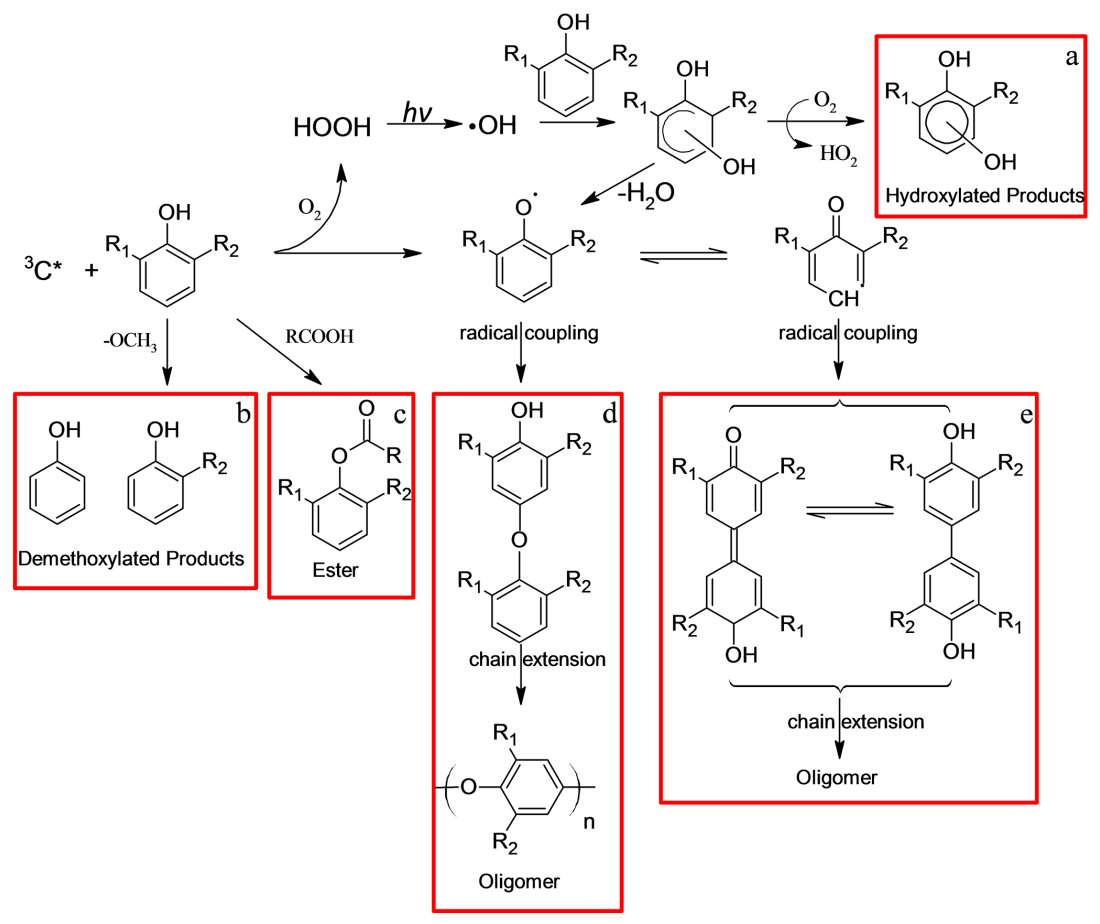

Figure 7. A schematic illustrates the formation of hydroxylated species, dimers and higher oligomers, esters, and demethoxylated products from aqueous photooxidation of phenolic compounds. Species produced via pathways a-e may undergo further ring-opening processes to form ketones and carboxylic acids. Phenol: $\mathrm{R}_{1}=\mathrm{H}, \mathrm{R}_{2}=\mathrm{H}$; Guaiacol: $\mathrm{R}_{1}=\mathrm{OCH}_{3}, \mathrm{R}_{2}=\mathrm{H}$; Syringol: $\mathrm{R}_{1}=\mathrm{OCH}_{3}, \mathrm{R}_{2}=\mathrm{OCH}_{3}$. Note that while radical coupling here is shown through the carbon opposite (para) the phenoxy group, other geometric isomers will also be formed during these reactions.

actions of phenols $+{ }^{3} \mathrm{C}^{*}$. Briefly, phenols react with ${ }^{3} \mathrm{C}^{*}$ and undergo multiple steps to form $\mathrm{HOOH}$ (Anastasio et al., 1997), which is a source of . $\mathrm{OH}$ via photolysis. The addition of $\cdot \mathrm{OH}$ to the aromatic ring, followed by $\mathrm{O}_{2}$ addition and $\mathrm{HO}_{2}$ elimination, leads to the formation of hydroxylated products (Barzaghi and Herrmann, 2002). In the meantime, the $\cdot \mathrm{OH}$-phenol adduct can undergo unimolecular elimination of $\mathrm{H}_{2} \mathrm{O}$ to form a phenoxy radical (Atkinson et al., 1992; Barzaghi and Herrmann, 2002; Olariu et al., 2002), which then combines with another radical to form dimer and higher oligomers. Note that the amount of $\mathrm{HOOH}$ produced in the reactions of phenols $+{ }^{3} \mathrm{C}^{*}$ is small and $\cdot \mathrm{OH}$ oxidation appears to be negligible compared to the oxidation of phenols by ${ }^{3} C^{*}$ (Smith et al., 2014). Phenoxy radical may also form from the oxidation of phenols by ${ }^{3} \mathrm{C}^{*}$ via electron transfer coupled with proton transfer from the phenoxyl radical cation or from solvent water (Anastasio et al., 1997). Demethoxylation takes place through attachment of $\cdot \mathrm{OH}$ to ring positions occupied by methoxyl groups, followed by elimination of a methanol molecule to form semiquinone radicals (Steenken and O'Neill, 1977). Esterification of phenols occurs through the reactions with organic acids (Offenhauer, 1964). Furthermore, the reactants and the products from all these pathways may undergo ring-opening process, forming ketones and carboxylic acids. Similar species, including oligomers, esters, carbonyls, carboxylic acids, and demethoxylated products, can be formed in $\cdot \mathrm{OH}$-mediated reactions as well (Sun et al., 2010), although apparently with different reaction yields and rates.

\subsection{Comparisons of phenolic aqSOA produced from different oxidants: • OH vs. ${ }^{3} \mathrm{C}^{*}$}

As discussed above, aqueous reactions of phenols produce a variety of low-volatility species including oligomers, functionalized monomer and oligomers (with varying numbers of carbonyl, carboxyl, ester, and hydroxyl groups), and small organic acids (e.g., formate, acetate, oxalate, and malate). Although aqSOA formed from the same precursor generally appear to be chemically similar, there are significant compositional differences between the products from $\cdot \mathrm{OH}$ and ${ }^{3} \mathrm{C}^{*}$ reactions. Overall, the molecular compositions of guaiacol and phenol aqSOA are more dependent on the oxidant than are syringol aqSOA (Fig. 5). Similarly, the AMS spectral patterns at $m / z \geq 80$ exhibit more significant differences between $\cdot \mathrm{OH}$ and ${ }^{3} \mathrm{C}^{*}$ for guaiacol $\left(r^{2}=0.65\right.$; Fig. $\left.2 \mathrm{j}\right)$ and phenol $\left(r^{2}=0.42\right.$; Fig. 21), whereas those for syringol are almost identical ( $r^{2}=0.97$; Fig. $2 \mathrm{~h}$ ). Furthermore, a majority of the aqSOA molecules of phenol $+\cdot \mathrm{OH}$ contain only one benzene ring, whereas the ${ }^{3} \mathrm{C}^{*}$ reaction produces more oligomers and substituted species based on the DBE values. 

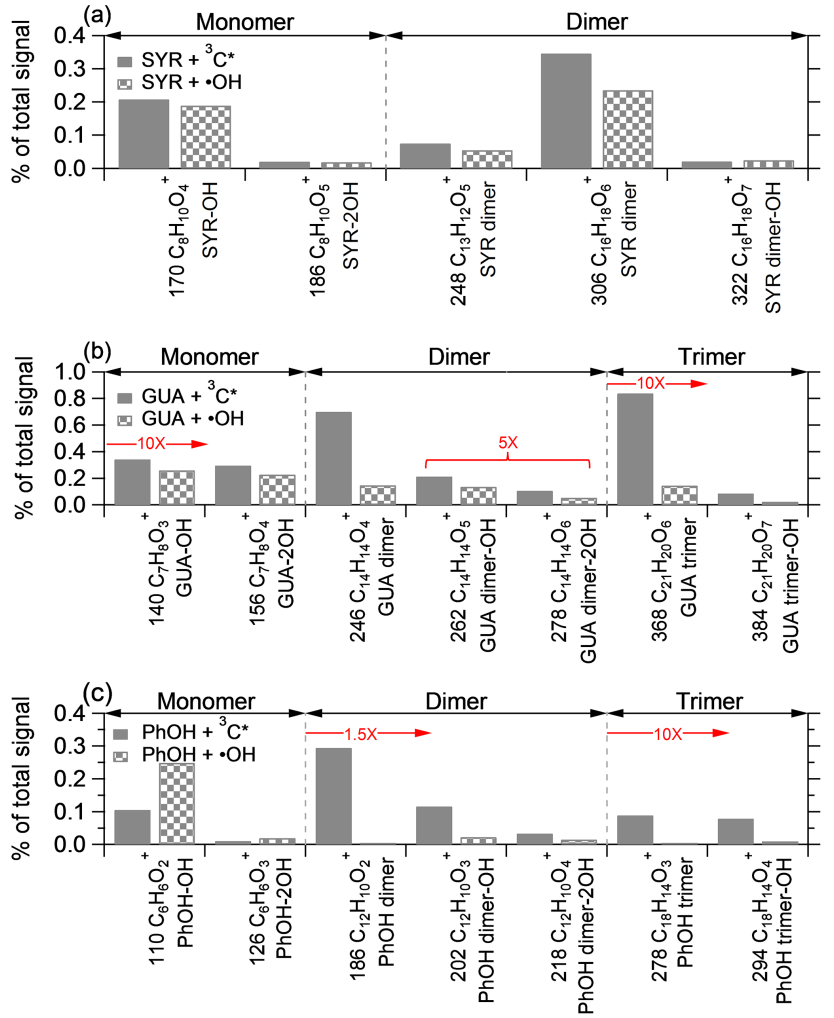

Figure 8. Comparisons of the relative abundances of signature ions in the AMS spectra of the aqSOA of (a) syringol (SYR), (b) guaiacol (GUA), and (c) phenol ( $\mathrm{PhOH})$ produced from ${ }^{3} \mathrm{C}^{*}$-mediated and $\cdot \mathrm{OH}$-mediated reactions. The signal contributions of certain signature ions are enhanced for clarity. The $m / z$ values of the signature ions are shown in front of the ion formula in the $x$ axes. Identities of possible parent compounds are shown to the right. $2 \mathrm{OH}$ represents two additional hydroxyl groups attached to the aromatic ring.

Since the fragmentation pattern from $70 \mathrm{eV}$ electron ionization is reproducible (McLafferty and Turecek, 1993), unique ions can be used as tracer species to quantify the concentration of the parent compound. Thus, we further compare the relative abundances of signature ions in the AMS spectra of the aqSOA formed from $\cdot \mathrm{OH}$ - and ${ }^{3} \mathrm{C}^{*}$-mediated reactions (Fig. 8). Details on the signature ions and their proposed precursors are given in Table S1. All these ions are oddelectron ions, which usually have special mechanistic significance and are more indicative of the chemical identities of the precursors (McLafferty and Turecek, 1993). These ions can potentially be used to analyze ambient organic aerosol data for the presence of phenolic aqSOA. For instance, a previous study by our group observed $\mathrm{C}_{16} \mathrm{H}_{18} \mathrm{O}_{6}^{+}(\mathrm{m} / z, 306)$ and $\mathrm{C}_{14} \mathrm{H}_{14} \mathrm{O}_{4}^{+}(m / z 246)$ - signature ions representing syringol and guaiacol dimers, respectively, in ambient aerosols significantly influenced by wood combustion and fog processing (Sun et al., 2010). Similar to the nano-DESI results, the AMS results also indicate that the aqSOA formed via ${ }^{3} \mathrm{C}^{*}$

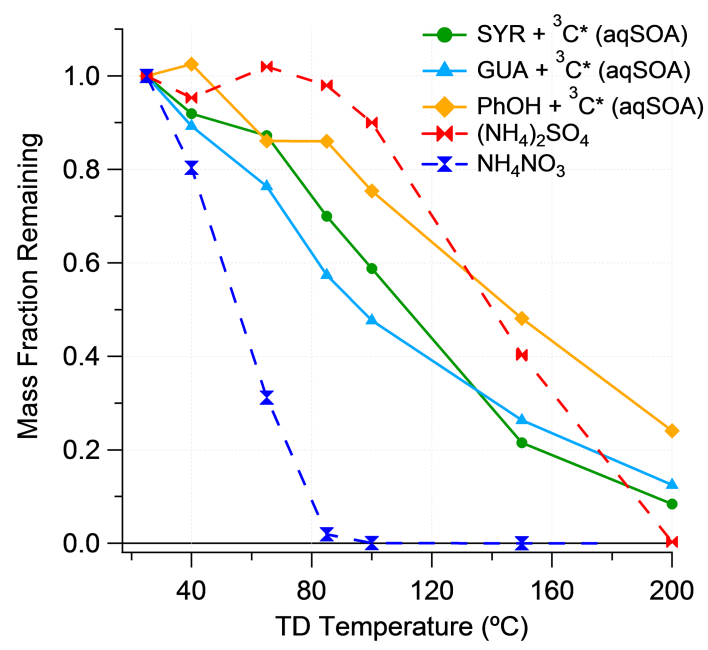

Figure 9. Mass thermograms of ammonium sulfate $\left(\left(\mathrm{NH}_{4}\right)_{2} \mathrm{SO}_{4}\right)$, ammonium nitrate $\left(\mathrm{NH}_{4} \mathrm{NO}_{3}\right)$, syringol (SYR), guaiacol (GUA), and phenol $(\mathrm{PhOH})$ aqSOA formed in ${ }^{3} \mathrm{C}^{*}$-mediated aqueous-phase reactions.

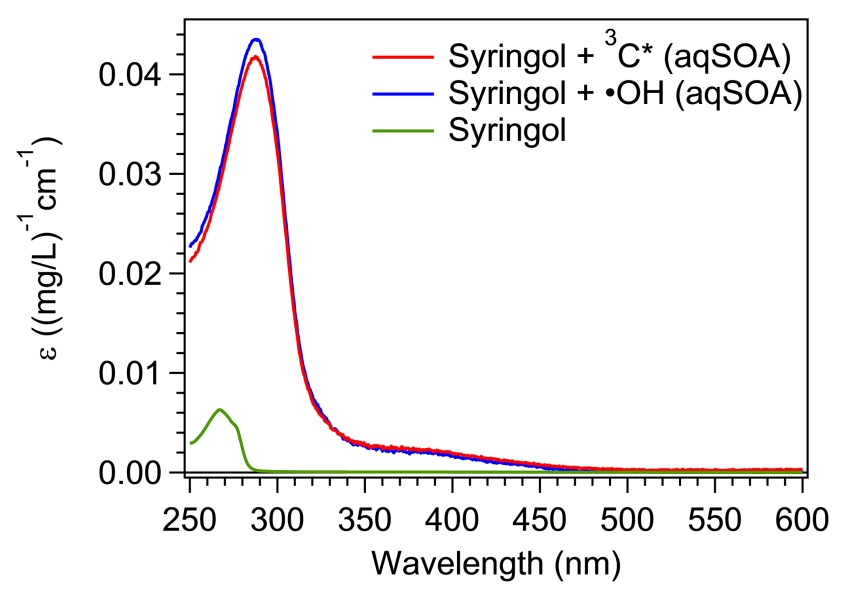

Figure 10. UV-visible spectra of syringol and syringol aqSOA formed in ${ }^{3} \mathrm{C}^{*}$-mediated and $\cdot \mathrm{OH}$-mediated aqueous-phase reactions. The aqSOA spectra were corrected for absorbance contributions from unreacted reactants (syringol and DMB).

are more enriched of dimers and higher oligomers compared to $\cdot \mathrm{OH}$ for a given phenol. These observations suggest that more coupling of phenoxy radicals takes place during reactions initiated by ${ }^{3} \mathrm{C}^{*}$ than by $\cdot \mathrm{OH}$. On the other hand, both $\mathrm{IC}$ and nano-DESI results indicate that $\cdot \mathrm{OH}$-mediated reactions promote the formation of organic acids and other ringopening species $\left(\mathrm{n}_{\mathrm{C}}<6\right)$ (see Sect. 3.2), consistent with the observations that $\cdot \mathrm{OH}$ reaction generally leads to more oxidized aqSOA as well as water-soluble volatile species (Table 1).

A possible reason for the compositional differences observed in the aqSOA of the same precursor but different oxidants is that ${ }^{3} \mathrm{C}^{*}$ reacts faster with phenols (Smith et 
al., 2014) and thus takes shorter time to oxidize the same amount of phenols compared to $\cdot \mathrm{OH}$. Longer illumination allows further oxidation and fragmentation of higher molecular weight species to happen, leading to the formation of smaller molecules with fewer aromatic rings. Indeed, the compositions of syringol aqSOA, which were produced after comparable illumination durations, are highly similar between the two oxidation conditions according to both nano-DESI and AMS results, whereas the difference is the largest for phenol aqSOA, whose illumination times are substantially different between ${ }^{3} \mathrm{C}^{*}$ and $\cdot \mathrm{OH}$ oxidation (Figs. 2 and 5). However, the fact that there are more oligomers and their derivatives in guaiacol $+{ }^{3} \mathrm{C}^{*}$ reaction compared to syringol $+\cdot \mathrm{OH}$ (Fig. 5) even though the illumination durations are similar (Table 1) suggests that coupling of phenoxy radicals is a more favored pathway through ${ }^{3} \mathrm{C}^{*}$ reaction.

\subsection{Volatility profiles and UV-visible absorption spectra of phenolic aqSOA}

As discussed above, the chemical compositions of phenolic aqSOA are complex. As a result, the volatilities of the aqSOA species span a broad range, from very low vapor pressure compounds such as oligomers to more volatile species such as low molecular weight acids. Figure 9 shows the volatility profiles of phenolic aqSOA formed from ${ }^{3} \mathrm{C}^{*}$ reactions measured by a thermodenuder coupled with the AMS. Ammonium sulfate and ammonium nitrate were analyzed simultaneously as references. On average, phenolic aqSOA are more volatile than ammonium sulfate, but less volatile than ammonium nitrate (Fig. 9). The fact that a significant fraction of the aqSOA mass remains in the particle phase even at $200^{\circ} \mathrm{C}$ (Fig. 9) is consistent with the presence of some very-lowvolatility species such as oligomers. Compared to guaiacol and syringol aqSOA, phenol aqSOA show the slowest decay with increasing TD temperature, indicating that they are comprised of more low-volatility species. This is consistent with our chemical analyses which reveal that the aqSOA of phenol $+{ }^{3} \mathrm{C}^{*}$ are composed of a larger fraction of species containing more than two aromatic rings, including trimer and higher oligomers (Fig. 5). This is also consistent with the fact that the $\mathrm{O} / \mathrm{C}$ ratios of phenol aqSOA are highest among all three precursors for the same oxidant. These results together suggest that the volatility of phenolic aqSOA is strongly influenced by both polymer contents and average oxidation degree, as reported previously (Huffman et al., 2009).

Recently, light-absorbing OA, also termed "brown carbon", has attracted much attention, due to its ability to absorb sunlight and thus affect the radiative budget of the earth (Shapiro et al., 2009). Previous studies have shown that the aqueous-phase oxidation of phenols forms low-volatility oligomers, which absorb significant amounts of UV-visible light and likely account for a significant portion of atmospheric HULIS (Gelencser et al., 2003; Chang and Thomp- son, 2010). In this study, we examined the optical properties of phenolic aqSOA using UV-visible spectroscopy. Figure 10 shows an example of the UV-visible spectra of syringol aqSOA formed in the reactions with ${ }^{3} \mathrm{C}^{*}$ and $\cdot \mathrm{OH}$, respectively, at $t_{1 / 2}$. Both syringol aqSOA samples absorb in the tropospheric sunlight wavelengths (> $300 \mathrm{~nm}$ ), while syringol does not. This enhancement is likely explained by the formation of conjugated structures as a result of polymerization and functionalization due to the additions of hydroxyl, carbonyl, and carboxyl functional groups to the aromatic rings. Phenol and guaiacol aqSOA also show enhanced absorption in the tropospheric sunlight wavelengths $(>300 \mathrm{~nm}$ ), while phenol and guaiacol themselves do not. These results indicate that aqueous-phase reactions of phenols are likely an important source of brown carbon in the atmosphere, especially in regions influenced by biomass burning.

\section{Conclusions and implications}

We thoroughly characterized the chemical composition and studied the volatility and optical properties of phenolic aqSOA formed via reactions with two different oxidants: ${ }^{3} \mathrm{C}^{*}$ and $\cdot \mathrm{OH}$. Elemental analysis of the AMS spectra indicates that all phenolic aqSOA are highly oxidized $(\mathrm{O} / \mathrm{C}$ ratios: $0.85-1.23)$, despite the fact that some of the reactions were very fast $\left(t_{1 / 2}<1 \mathrm{~h}\right.$ for syringol). For the same oxidant, the oxidation degree of the aqSOA formed at $t_{1 / 2}$ follows the order: phenol > guaiacol > syringol. A large number of aqSOA molecules are identified, including oligomers (up to hexamers) and their derivatives with varying numbers of carbonyl, carboxyl, ester, and hydroxyl groups. A large number of ring-opening species $\left(\mathrm{n}_{\mathrm{C}}<6\right)$ including small organic acids (e.g., oxalate, formate, and acetate) are also identified. While the bulk compositions of the aqSOA are overall similar at $t_{1 / 2}$ between the two oxidants for a given precursor, compositional differences are observed. Generally speaking, reactions mediated by $\cdot \mathrm{OH}$ produce more highly oxygenated species with a single aromatic ring, while oxidation by ${ }^{3} \mathrm{C}^{*}$ enhances the formation of higher molecular weight species including oligomers and their oxygenated derivatives. The physical properties, such as volatility and light absorptivity, of the phenol aqSOA depend on their chemical compositions. Our thermodenuder experiments indicate that the volatility profiles of phenolic aqSOA are influenced by both oligomer contents and average oxidation degree. In addition, the formation of aqSOA species with enhanced conjugated double bonds is probably responsible for the significant light absorption in the actinic region, suggesting that aqueous-phase reactions of phenols are an important source of brown carbon in the atmosphere.

Overall, our results indicate that aqueous-phase processing of phenols represents an important pathway for the production of low-volatility, highly oxygenated, and high molec- 
ular weight species, which remain in the particle phase after water evaporation. Since phenolic aqSOA is both water soluble and light absorbing, understanding the impacts of these reactions on the chemical and physical properties, and thus the climatic and health effects, of atmospheric particles may be important, especially in regions influenced by biomass burning emissions. An approach for evaluating the importance of phenolic aqSOA formation in the atmosphere is to systematically analyze the AMS mass spectra of ambient aerosol for signature ions representative of phenolic aqSOA. AMS has been broadly applied for chemical analysis of ambient aerosol, and multivariate statistical approaches (e.g., positive matrix factorization) have been frequently used on organic aerosol mass spectral data to determine factors representing different sources and processes (Ulbrich et al., 2009; Zhang et al., 2011). An important criterion for validating the extracted factor is via examining the mass spectra of the factors for signature ions (Zhang et al., 2011). The fact that AMS uses $70 \mathrm{eV}$ EI ionization, which ionizes and fragments molecules with a reproducible pattern (McLafferty and Turecek, 1993), allows for the identification and quantification of certain compounds or compound classes in a mixture via signature ions. Indeed, previous studies have demonstrated the capability of using unique AMS ions to fingerprint species such as hydrocarbon-like and oxygenated organic aerosols (Zhang et al., 2005), polycyclic aromatic hydrocarbons (PAH) (Dzepina et al., 2007), methanesulfonic acid (MSA) (Ge et al., 2012), and certain nitrogenand sulfur-containing organic aerosols (Farmer et al., 2010; Ge et al., 2014).

With this in mind, this study suggests several ions that are potentially representative of phenolic aqSOA, including $\mathrm{C}_{16} \mathrm{H}_{18} \mathrm{O}_{6}^{+}(m / z=306)$ for syringol dimer, $\mathrm{C}_{14} \mathrm{H}_{14} \mathrm{O}_{4}^{+}$ $(m / z=246)$ for guaiacol dimer, $\mathrm{C}_{14} \mathrm{H}_{14} \mathrm{O}_{5}^{+}(m / z=262)$ and $\mathrm{C}_{14} \mathrm{H}_{14} \mathrm{O}_{6}^{+}(m / z=278)$ for hydroxylated guaiacol dimer, $\mathrm{C}_{12} \mathrm{H}_{10} \mathrm{O}_{2}^{+}(m / z=186)$ for phenol dimer, $\mathrm{C}_{21} \mathrm{H}_{20} \mathrm{O}_{6}^{+}$ $(m / z=368)$ for guaiacol trimer, and $\mathrm{C}_{18} \mathrm{H}_{14} \mathrm{O}_{3}^{+}(m / z=278)$ for phenol trimer (Fig. 8). Since all these ions have odd number of electrons with relatively high $\mathrm{m} / \mathrm{z}$ 's, their production in the AMS is more directly linked to the specific parent compounds, meaning that they are less likely to be contributed by confounding molecules (McLafferty and Turecek, 1993). In addition, while large hydrocarbon molecules, e.g., those from vehicle emissions, may generate significant ion signals at $m / z>200$, most of them are even-electron ions and contain no oxygen. They are therefore easily differentiated from the isobaric ions from phenolic SOA. Nevertheless, it is important to point out that the validity of using the aqSOA signature ions identified in this study needs to be evaluated by examining ambient organic aerosol mass spectrometry data. In addition, analyzing field samples with nano-DESI may also provide important insights into the impacts of aqueous phase processing of phenolic compounds in the atmosphere.

\section{The Supplement related to this article is available online at doi:10.5194/acp-14-13801-2014-supplement.}

Acknowledgements. This work was supported by the US National Science Foundation, grant no. AGS-1036675 and the California Agricultural Experiment Station (Projects CA-D-ETX-2102-H and CA-D*-LAW-6403-RR). The nano-DESI MS analysis was performed at the W. R. Wiley Environmental Molecular Sciences Laboratory (EMSL) - a national scientific user facility located at PNNL, and sponsored by the Office of Biological and Environmental Research of the US PNNL is operated for US DOE by Battelle Memorial Institute under contract no. DE-AC06-76RL0 1830. Additional funding was provided by a Jastro Shields Graduate Research Award (UCDavis) and graduate fellowships from the Atmospheric Aerosols and Health (AAH) program at UC Davis to L. Yu and J. Smith. We thank Ann Dillner, Kathryn George, and Sonya Collier for help with experiments.

Edited by: A. Nenes

\section{References}

Aiken, A. C., Decarlo, P. F., Kroll, J. H., Worsnop, D. R., Huffman, J. A., Docherty, K. S., Ulbrich, I. M., Mohr, C., Kimmel, J. R., Sueper, D., Sun, Y., Zhang, Q., Trimborn, A., Northway, M., Ziemann, P. J., Canagaratna, M. R., Onasch, T. B., Alfarra, M. R., Prevot, A. S. H., Dommen, J., Duplissy, J., Metzger, A., Baltensperger, U., and Jimenez, J. L.: O / C and OM / OC ratios of primary, secondary, and ambient organic aerosols with highresolution time-of-flight aerosol mass spectrometry, Environ. Sci. Technol., 42, 4478-4485, doi:10.1021/es703009q, 2008.

Allan, J. D., Delia, A. E., Coe, H., Bower, K. N., Alfarra, M. R., Jimenez, J. L., Middlebrook, A. M., Drewnick, F., Onasch, T. B., Canagaratna, M. R., Jayne, J. T., and Worsnop, D. R.: A generalised method for the extraction of chemically resolved mass spectra from Aerodyne aerosol mass spectrometer data, J. Aerosol Sci., 35, 909-922, doi:10.1016/j.jaerosci.2004.02.007, 2004.

Altieri, K. E., Carlton, A. G., Lim, H. J., Turpin, B. J., and Seitzinger, S. P.: Evidence for oligomer formation in clouds: reactions of isoprene oxidation products, Environ. Sci. Technol., 40, 4956-4960, doi:10.1021/es052170n, 2006.

Anastasio, C. and McGregor, K. G.: Chemistry of fog waters in California's Central Valley: 1. In situ photoformation of hydroxyl radical and singlet molecular oxygen, Atmos. Environ., 35, 1079-1089, doi:10.1016/s1352-2310(00)00281-8, 2001.

Anastasio, C., Faust, B. C., and Rao, C. J.: Aromatic carbonyl compounds as aqueous-phase photochemical sources of hydrogen peroxide in acidic sulfate aerosols, fogs, and clouds .1. Non-phenolic methoxybenzaldehydes and methoxyacetophenones with reductants (phenols), Environ. Sci. Technol., 31, 218232, doi:10.1021/es960359g, 1997

Arakaki, T., Anastasio, C., Kuroki, Y., Nakajima, H., Okada, K., Kotani, Y., Handa, D., Azechi, S., Kimura, T., Tsuhako, A., and Miyagi, Y.: A General Scavenging Rate Constant for Reaction of 
Hydroxyl Radical with Organic Carbon in Atmospheric Waters, Environ. Sci. Technol., 47, 8196-8203, doi:10.1021/es401927b, 2013.

Aregahegn, K. Z., Noziere, B., and George, C.: Organic aerosol formation photo-enhanced by the formation of secondary photosensitizers in aerosols, Faraday Disc., 165, 123-134, doi:10.1039/C3FD00044C, 2013.

Atkinson, R., Aschmann, S. M., and Arey, J.: Reactions of hydroxyl and nitrogen trioxide radicals with phenol, cresols, and 2nitrophenol at $296 \pm 2 \mathrm{~K}$, Environ. Sci. Technol., 26, 1397-1403, doi:10.1021/es00031a018, 1992.

Barzaghi, P., and Herrmann, H.: A mechanistic study of the oxidation of phenol by $\mathrm{OH} / \mathrm{NO}_{2} / \mathrm{NO}_{3}$ in aqueous solution, Phys. Chem. Chem. Phys., 4, 3669-3675, doi:10.1039/b201652d, 2002.

Bateman, A. P., Laskin, J., Laskin, A., and Nizkorodov, S. A.: Applications of high-resolution electrospray ionization mass spectrometry to measurements of average oxygen to carbon ratios in secondary organic aerosols, Environ. Sci. Technol., 46, 83158324, doi:10.1021/es3017254, 2012.

Blando, J. D. and Turpin, B. J.: Secondary organic aerosol formation in cloud and fog droplets: a literature evaluation of plausibility, Atmos. Environ., 34, 1623-1632, doi:10.1016/S13522310(99)00392-1, 2000.

Canagaratna, M. R., Jayne, J. T., Jimenez, J. L., Allan, J. D., Alfarra, M. R., Zhang, Q., Onasch, T. B., Drewnick, F., Coe, H., Middlebrook, A., Delia, A., Williams, L. R., Trimborn, A. M., Northway, M. J., DeCarlo, P. F., Kolb, C. E., Davidovits, P., and Worsnop, D. R.: Chemical and microphysical characterization of ambient aerosols with the aerodyne aerosol mass spectrometer, Mass Spectrom. Rev., 26, 185-222, doi:10.1002/mas.20115, 2007.

Canonica, S., Hellrung, B., and Wirz, J.: Oxidation of phenols by triplet aromatic ketones in aqueous solution, J. Phys. Chem. A, 104, 1226-1232, doi:10.1021/jp9930550, 2000.

Chang, J. L., and Thompson, J. E.: Characterization of colored products formed during irradiation of aqueous solutions containing $\mathrm{H}_{2} \mathrm{O}_{2}$ and phenolic compounds, Atmos. Environ., 44, 541-551, doi:10.1016/j.atmosenv.2009.10.042, 2010.

Chhabra, P. S., Ng, N. L., Canagaratna, M. R., Corrigan, A. L., Russell, L. M., Worsnop, D. R., Flagan, R. C., and Seinfeld, J. H.: Elemental composition and oxidation of chamber organic aerosol, Atmos. Chem. Phys., 11, 8827-8845, doi:10.5194/acp-11-88272011, 2011.

Collier, S., and Zhang, Q.: Gas-phase CO2 subtraction for improved measurements of the organic aerosol mass concentration and oxidation degree by an aerosol mass spectrometer, Environ. Sci. Technol., 47, 14324-14331, doi:10.1021/es404024h, 2013.

DeCarlo, P. F., Kimmel, J. R., Trimborn, A., Northway, M. J., Jayne, J. T., Aiken, A. C., Gonin, M., Fuhrer, K., Horvath, T., Docherty, K. S., Worsnop, D. R., and Jimenez, J. L.: Field-deployable, high-resolution, time-of-flight aerosol mass spectrometer, Anal. Chem., 78, 8281-8289, doi:10.1021/ac061249n, 2006.

Dzepina, K., Arey, J., Marr, L. C., Worsnop, D. R., Salcedo, D., Zhang, Q., Onasch, T. B., Molina, L. T., Molina, M. J., and Jimenez, J. L.: Detection of particle-phase polycyclic aromatic hydrocarbons in Mexico City using an aerosol mass spectrometer, Int. J. Mass Spectrom., 263, 152-170, doi:10.1016/j.ijms.2007.01.010, 2007.
Ervens, B., Turpin, B. J., and Weber, R. J.: Secondary organic aerosol formation in cloud droplets and aqueous particles (aqSOA): a review of laboratory, field and model studies, Atmos. Chem. Phys., 11, 11069-11102, doi:10.5194/acp-1111069-2011, 2011.

Farmer, D. K., Matsunaga, A., Docherty, K. S., Surratt, J. D., Seinfeld, J. H., Ziemann, P. J., and Jimenez, J. L.: Response of an aerosol mass spectrometer to organonitrates and organosulfates and implications for atmospheric chemistry, Proc. Natl. Acad. Sci., 107, 6670-6675, doi:10.1073/pnas.0912340107, 2010.

Fierz, M., Vernooij, M. G. C., and Burtscher, H.: An improved low-flow thermodenuder, J. Aerosol Sci., 38, 1163-1168, doi:10.1016/j.jaerosci.2007.08.006, 2007.

Ge, X., Setyan, A., Sun, Y., and Zhang, Q.: Primary and secondary organic aerosols in Fresno, California during wintertime: Results from high resolution aerosol mass spectrometry, J. Geophys. Res., 117, D19301, doi:10.1029/2012JD018026, 2012.

Ge, X., Shaw, S. L., and Zhang, Q.: Toward understanding amines and their degradation products from postcombustion $\mathrm{CO} 2$ capture processes with aerosol mass spectrometry, Environ. Sci. Technol., 48, 5066-5075, doi:10.1021/es4056966, 2014.

Gelencser, A., Hoffer, A., Kiss, G., Tombacz, E., Kurdi, R., and Bencze, L.: In-situ formation of light-absorbing organic matter in cloud water, J. Atmos. Chem., 45, 25-33, doi:10.1023/a:1024060428172, 2003.

George, K. M., Ruthenburg, T. C., Smith, J. D., Anastasio, C., Yu, L., Zhang, Q., and Dillner, A.: FT-IR quantification of the carbonyl functional group in aqueous-phase secondary organic aerosol from phenols, Atmos. Environ., 100, 230-237, doi:10.1016/j.atmosenv.2014.11.011, 2015

Hallquist, M., Wenger, J. C., Baltensperger, U., Rudich, Y., Simpson, D., Claeys, M., Dommen, J., Donahue, N. M., George, C., Goldstein, A. H., Hamilton, J. F., Herrmann, H., Hoffmann, T., Iinuma, Y., Jang, M., Jenkin, M. E., Jimenez, J. L., KiendlerScharr, A., Maenhaut, W., McFiggans, G., Mentel, T. F., Monod, A., Prevot, A. S. H., Seinfeld, J. H., Surratt, J. D., Szmigielski, R., and Wildt, J.: The formation, properties and impact of secondary organic aerosol: current and emerging issues, Atmos. Chem. Phys., 9, 5155-5236, doi:10.5194/acp-9-5155-2009, 2009.

Hawthorne, S. B., Krieger, M. S., Miller, D. J., and Mathiason, M. B.: Collection and quantitation of methoxylated phenol tracers for atmospheric-pollution from residential wood stoves, Environ. Sci. Technol., 23, 470-475, doi:10.1021/es00181a013, 1989.

Hawthorne, S. B., Miller, D. J., Langenfeld, J. J., and Krieger, M. S.: PM-10 high-volume collection and quantitation of semi- and nonvolatile phenols, methoxylated phenols, alkanes, and polycyclic aromatic hydrocarbons from winter urban air and their relationship to wood smoke emissions, Environ. Sci. Technol., 26, 2251-2262, doi:10.1021/es00035a026, 1992.

Huffman, J. A., Docherty, K. S., Mohr, C., Cubison, M. J., Ulbrich, I. M., Ziemann, P. J., Onasch, T. B., and Jimenez, J. L.: Chemically-resolved volatility measurements of organic aerosol from different sources, Environ. Sci. Technol., 43, 5351-5357, doi:10.1021/es803539d, 2009.

Hughey, C. A., Hendrickson, C. L., Rodgers, R. P., Marshall, A. G., and Qian, K. N.: Kendrick mass defect spectrum: A compact visual analysis for ultrahigh-resolution broadband mass spectra, Anal. Chem., 73, 4676-4681, doi:10.1021/ac010560w, 2001. 
Jaitly, N., Mayampurath, A., Littlefield, K., Adkins, J. N., Anderson, G. A., and Smith, R. D.: Decon2LS: An open-source software package for automated processing and visualization of high resolution mass spectrometry data, BMC Bioinformatics, 10, 87, doi:10.1186/1471-2105-10-87, 2009.

Jimenez, J. L., Canagaratna, M. R., Donahue, N. M., Prevot, A. S. H., Zhang, Q., Kroll, J. H., DeCarlo, P. F., Allan, J. D., Coe, H., Ng, N. L., Aiken, A. C., Docherty, K. S., Ulbrich, I. M., Grieshop, A. P., Robinson, A. L., Duplissy, J., Smith, J. D., Wilson, K. R., Lanz, V. A., Hueglin, C., Sun, Y. L., Tian, J., Laaksonen, A., Raatikainen, T., Rautiainen, J., Vaattovaara, P., Ehn, M., Kulmala, M., Tomlinson, J. M., Collins, D. R., Cubison, M. J., Dunlea, E. J., Huffman, J. A., Onasch, T. B., Alfarra, M. R., Williams, P. I., Bower, K., Kondo, Y., Schneider, J., Drewnick, F., Borrmann, S., Weimer, S., Demerjian, K., Salcedo, D., Cottrell, L., Griffin, R., Takami, A., Miyoshi, T., Hatakeyama, S., Shimono, A., Sun, J. Y., Zhang, Y. M., Dzepina, K., Kimmel, J. R., Sueper, D., Jayne, J. T., Herndon, S. C., Trimborn, A. M., Williams, L. R., Wood, E. C., Middlebrook, A. M., Kolb, C. E., Baltensperger, U., and Worsnop, D. R.: Evolution of organic aerosols in the atmosphere, Science, 326, 1525-1529, doi:10.1126/science.1180353, 2009.

Kanakidou, M., Seinfeld, J. H., Pandis, S. N., Barnes, I., Dentener, F. J., Facchini, M. C., Van Dingenen, R., Ervens, B., Nenes, A., Nielsen, C. J., Swietlicki, E., Putaud, J. P., Balkanski, Y., Fuzzi, S., Horth, J., Moortgat, G. K., Winterhalter, R., Myhre, C. E. L., Tsigaridis, K., Vignati, E., Stephanou, E. G., and Wilson, J.: Organic aerosol and global climate modelling: a review, Atmos. Chem. Phys., 5, 1053-1123, doi:10.5194/acp-5-1053-2005, 2005.

Kruve, A., Kaupmees, K., Liigand, J., and Leito, I.: Negative Electrospray Ionization via Deprotonation: Predicting the Ionization Efficiency, Anal. Chem., 86, 4822-4830, doi:10.1021/ac404066v, 2014.

Leuenberger, C., Ligocki, M. P., and Pankow, J. F.: Trace organic compounds in rain. 4. Identities, concentrations, and scavenging mechanisms for phenols in urban air and rain, Environ. Sci. Technol., 19, 1053-1058, doi:10.1021/es00141a005, 1985.

Lim, H. J., Carlton, A. G., and Turpin, B. J.: Isoprene forms secondary organic aerosol through cloud processing: Model simulations, Environ. Sci. Technol., 39, 4441-4446, doi:10.1021/es048039h, 2005.

McLafferty, F. W. and Turecek, F.: Interpretation of Mass Spectra, University Science Books, Mill Valley, California, 1993.

Monge, M. E., Rosenørn, T., Favez, O., Müller, M., Adler, G., Abo Riziq, A., Rudich, Y., Herrmann, H., George, C., and D'Anna, B.: Alternative pathway for atmospheric particles growth, P. Natl. Acad. Sci., 109, 6840-6844, doi:10.1073/pnas.1120593109, 2012.

Murphy, D. M., Cziczo, D. J., Froyd, K. D., Hudson, P. K., Matthew, B. M., Middlebrook, A. M., Peltier, R. E., Sullivan, A., Thomson, D. S., and Weber, R. J.: Single-particle mass spectrometry of tropospheric aerosol particles, J. Geophys. Res.-Atmos., 111, D23S32, doi:10.1029/2006jd007340, 2006.

Offenhauer, R. D.: The direct esterification of phenols, J. Chem. Educ., 41, 39, doi:10.1021/ed041p39, 1964.

Ofner, J., Krüger, H. U., Grothe, H., Schmitt-Kopplin, P., Whitmore, K., and Zetzsch, C.: Physico-chemical characterization of SOA derived from catechol and guaiacol - a model substance for the aromatic fraction of atmospheric HULIS, Atmos. Chem. Phys., 11, 1-15, doi:10.5194/acp-11-1-2011, 2011.

Olariu, R. I., Klotz, B., Barnes, I., Becker, K. H., and Mocanu, R.: FT-IR study of the ring-retaining products from the reaction of $\mathrm{OH}$ radicals with phenol, o-, m-, and p-cresol, Atmos. Environ., 36, 3685-3697, doi:10.1016/s1352-2310(02)00202-9, 2002.

Pellegrin, V.: Molecular formulas of organic compounds: the nitrogen rule and degree of unsaturation, J. Chem. Educ., 60, 626633, doi:10.1021/ed060p626, 1983.

Roach, P. J., Laskin, J., and Laskin, A.: Molecular characterization of organic aerosols using nanospray-desorption/electrospray ionization-mass spectrometry, Anal. Chem., 82, 7979-7986, doi:10.1021/ac101449p, 2010a.

Roach, P. J., Laskin, J., and Laskin, A.: Nanospray desorption electrospray ionization: an ambient method for liquid-extraction surface sampling in mass spectrometry, Analyst, 135, 2233-2236, doi:10.1039/c0an00312c, 2010b.

Roach, P. J., Laskin, J., and Laskin, A.: Higher-order mass defect analysis for mass spectra of complex organic mixtures, Anal. Chem., 83, 4924-4929, doi:10.1021/ac200654j, 2011.

Rossignol, S., Aregahegn, K. Z., Tinel, L., Fine, L., Noziere, B., and George, C.: Glyoxal Induced Atmospheric Photosensitized Chemistry Leading to Organic Aerosol Growth, Environ. Sci. Technol., 48, 3218-3227, doi:10.1021/es405581g, 2014.

Sagebiel, J. C. and Seiber, J. N.: Studies on the occurrence and distribution of wood smoke marker compounds in foggy atmospheres, Environ. Toxicol. Chem., 12, 813-822, doi:10.1002/etc.5620120504, 1993.

Sander, R.: Compilation of Henry's Law constants for inorganic and organic species of potential importance in environmental chemistry, available at: http://irs.ub.rug.nl/dbi/4581696d8b3ed (last access: 14 December 2006), 1999.

Schauer, J. J., Kleeman, M. J., Cass, G. R., and Simoneit, B. R. T.: Measurement of emissions from air pollution sources. 3. C1-C-29 organic compounds from fireplace combustion of wood, Environ. Sci. Technol., 35, 1716-1728, doi:10.1021/es001331e, 2001.

Shapiro, E. L., Szprengiel, J., Sareen, N., Jen, C. N., Giordano, M. R., and McNeill, V. F.: Light-absorbing secondary organic material formed by glyoxal in aqueous aerosol mimics, Atmos. Chem. Phys., 9, 2289-2300, doi:10.5194/acp-9-2289-2009, 2009.

Simoneit, B. R. T., Schauer, J. J., Nolte, C. G., Oros, D. R., Elias, V. O., Fraser, M. P., Rogge, W. F., and Cass, G. R.: Levoglucosan, a tracer for cellulose in biomass burning and atmospheric particles, Atmos. Environ., 33, 173-182, doi:10.1016/s13522310(98)00145-9, 1999.

Smith, J. D., Sio, V., Yu, L., Zhang, Q., and Anastasio, C.: Secondary organic aerosol production from aqueous reactions of atmospheric phenols with an organic triplet excited state, Environ. Sci. Technol., 48, 1049-1057, doi:10.1021/es4045715, 2014

Steenken, S. and O'Neill, P.: Oxidative demethoxylation of methoxylated phenols and hydroxybenzoic acids by the hydroxyl radical. An in situ electron spin resonance, conductometric pulse radiolysis and product analysis study, J. Phys. Chem., 81, 505508, doi:10.1021/j100521a002, 1977.

Sun, Y., Zhang, Q., Macdonald, A. M., Hayden, K., Li, S. M., Liggio, J., Liu, P. S. K., Anlauf, K. G., Leaitch, W. R., Steffen, A., Cubison, M., Worsnop, D. R., van Donkelaar, A., and Martin, R. V.: Size-resolved aerosol chemistry on Whistler Mountain, 
Canada with a high-resolution aerosol mass spectrometer during INTEX-B, Atmos. Chem. Phys., 9, 3095-3111, doi:10.5194/acp9-3095-2009, 2009.

Sun, Y. L., Zhang, Q., Anastasio, C., and Sun, J.: Insights into secondary organic aerosol formed via aqueous-phase reactions of phenolic compounds based on high resolution mass spectrometry, Atmos. Chem. Phys., 10, 4809-4822, doi:10.5194/acp-104809-2010, 2010.

Ulbrich, I. M., Canagaratna, M. R., Zhang, Q., Worsnop, D. R., and Jimenez, J. L.: Interpretation of organic components from Positive Matrix Factorization of aerosol mass spectrometric data, Atmos. Chem. Phys., 9, 2891-2918, doi:10.5194/acp-9-2891-2009, 2009.

Yee, L. D., Kautzman, K. E., Loza, C. L., Schilling, K. A., Coggon, M. M., Chhabra, P. S., Chan, M. N., Chan, A. W. H., Hersey, S. P., Crounse, J. D., Wennberg, P. O., Flagan, R. C., and Seinfeld, J. H.: Secondary organic aerosol formation from biomass burning intermediates: phenol and methoxyphenols, Atmos. Chem. Phys., 13, 8019-8043, doi:10.5194/acp-13-8019-2013, 2013.

Zhang, Q., Alfarra, M. R., Worsnop, D. R., Allan, J. D., Coe, H., Canagaratna, M. R., and Jimenez, J. L.: Deconvolution and quantification of hydrocarbon-like and oxygenated organic aerosols based on aerosol mass spectrometry, Environ. Sci. Technol., 39, 4938-4952, doi:10.1021/es0485681, 2005.
Zhang, Q., Jimenez, J. L., Canagaratna, M. R., Allan, J. D., Coe, H., Ulbrich, I., Alfarra, M. R., Takami, A., Middlebrook, A. M., Sun, Y. L., Dzepina, K., Dunlea, E., Docherty, K., DeCarlo, P. F., Salcedo, D., Onasch, T., Jayne, J. T., Miyoshi, T., Shimono, A., Hatakeyama, S., Takegawa, N., Kondo, Y., Schneider, J., Drewnick, F., Borrmann, S., Weimer, S., Demerjian, K., Williams, P., Bower, K., Bahreini, R., Cottrell, L., Griffin, R. J., Rautiainen, J., Sun, J. Y., Zhang, Y. M., and Worsnop, D. R.: Ubiquity and dominance of oxygenated species in organic aerosols in anthropogenically-influenced Northern Hemisphere midlatitudes, Geophys. Res. Lett., 34, L13801, doi:10.1029/2007GL029979, 2007.

Zhang, Q., Jimenez, J., Canagaratna, M., Ulbrich, I., Ng, N., Worsnop, D., and Sun, Y.: Understanding atmospheric organic aerosols via factor analysis of aerosol mass spectrometry: a review, Anal. Bioanal. Chem., 401, 3045-3067, doi:10.1007/s00216-011-5355-y, 2011. 